\title{
Iron Ore Slimes Flotation Tests Using Column and Amidoamine Collector without Depressant
}

\author{
Lev O. Filippov ${ }^{1, *}$ (), Klaydison Silva ${ }^{1,2}$, Alexandre Piçarra ${ }^{1}$, Neymayer Lima ${ }^{2}$, Iranildes Santos ${ }^{3}$, \\ Leandro Bicalho ${ }^{4}$, Inna V. Filippova ${ }^{1}$ and Antonio Eduardo Clark Peres ${ }^{5}$ \\ 1 Department for Georessources, Université de Lorraine, CNRS, GeoRessources, F54000 Nancy, France; \\ klaydison.silva@vale.com (K.S.); alexandre.palma-picarra@univ-lorraine.fr (A.P.); \\ inna.filippova@univ-lorraine.fr (I.V.F.) \\ 2 VALE S.A.-Iron Ore Beneficiation Development Team, Nova Lima 34006-200, Brazil; \\ neymayer.lima@vale.com \\ 3 Vale Institute of Technology, Ouro Preto 35400-000, Brazil; iranildes.santos@itv.org \\ 4 Clariant, Belo Horizonte 31710-400, Brazil; leandro.bicalho@clariant.com \\ 5 Department of Metallurgical and Materials Engineering, Engineering School, UFMG (Federal University of \\ Minas Gerais), Belo Horizonte 31270-901, Brazil; aecperes@demet.ufmg.br \\ * Correspondence: lev.filippov@univ-lorraine.fr
}

check for updates

Citation: Filippov, L.O.; Silva, K.; Piçarra, A.; Lima, N.; Santos, I.; Bicalho, L.; Filippova, I.V.; Peres, A.E.C. Iron Ore Slimes Flotation Tests Using Column and Amidoamine Collector without Depressant. Minerals 2021, 11, 699. https:// doi.org/10.3390/min11070699

Academic Editor: Przemyslaw B. Kowalczuk

Received: 8 May 2021

Accepted: 21 June 2021

Published: 29 June 2021

Publisher's Note: MDPI stays neutral with regard to jurisdictional claims in published maps and institutional affiliations.

Copyright: (c) 2021 by the authors. Licensee MDPI, Basel, Switzerland. This article is an open access article distributed under the terms and conditions of the Creative Commons Attribution (CC BY) license (https:/ / creativecommons.org/licenses/by/ $4.0 /)$.

\begin{abstract}
This work describes the concentration of iron ore slimes on a pilot scale by using a 500-mm diameter flotation column and a novel collector, which renders the use of a depressant unnecessary. The pilot column was operated in series with the industrial plant Vargem Grande 2 (Iron Quadrangle, Brazil) receiving, as feed, part of the underflow from the desliming thickener. These pilot tests represented only the rougher stage of a flotation circuit. The novel collector used was an amidoamine (average collector dosage of $160 \mathrm{~g} / \mathrm{t}$ ), and the tests were carried out in the absence of starch, at $\mathrm{pH} 10.5$ and with bubbles/microbubbles generated by cavitation tube. It was possible to achieve a concentrate, by reverse flotation, with an average iron content of $53 \%$ and an average metallurgical recovery of $91.5 \%$ The recovery of the silica in the froth was $53.1 \%$ in average for one stage of flotation. The high variability of the slime characteristics rendered difficult the stabilization of the $\mathrm{SiO}_{2}$ recovery; however, the applicability of the amidoamine collector was proven. In an industrial scale circuit, the use of online analyzers for $\mathrm{Fe}$ and $\mathrm{SiO}_{2}$ content and the adoption of control logics based on the adjustment of parameters such as reagents dosage and washing water flow rate adjustment should contribute to the optimization of the results obtained in the pilot scale tests. Further studies adding a cleaner concentration stage should be performed.
\end{abstract}

Keywords: iron ore; slimes; column flotation; amidoamine; pilot plant; Vargem Grande 2

\section{Introduction \\ 1.1. Iron Ore Ultrafines Concentration}

The harmful effect of slime on quartz reverse flotation has been known since the beginning of iron ore flotation operations. The removal of slimes using hydrocyclones was introduced by United States Bureau of Mines (USBM) [1]. The high consumption of reagents and the difficulty to remove ultrafine quartz and the high amount of deleterious minerals, such as kaolinite, are the main issues due to the presence of slimes in the flotation [2].

The high stability of the froth is also an important characteristic regarding slimes presence in flotation systems. Achaye [3] showed that froth stability decreases with increasing particle size and fine particles had the greatest influence on froth stability. Some authors $[4,5]$ investigated the relationship between froth stability, size distribution, and air recovery, demonstrating there is an ideal air rate for each particle size distribution.

The traditional view states that ultra-fine particles have a lesser flotation selectivity than coarse particles, nevertheless, some ores must be ground to ultrafine sizes to reach the 
required liberation degree [6]. According to Haselhuhn and Kawatra [7], the selective flocculation and dispersion desliming followed by reverse cationic flotation is the only proven method for the beneficiation of fine-grained $(<25 \mu \mathrm{m})$ hematite ores. This process was developed by USBM as an alternative method to the desliming process by hydrocyclones, which generates a high loss of iron in the slime [8].

Weissenborn et al. [9] studied the selective flocculation process for a plant of BHP Iron Ore and concluded that careful control of the many process variables was required to achieve optimum recovery. The industrial selective flocculation process was introduced at Tilden Mine prior to the flotation circuit, where the passing size of $80 \%$ of the grinding product ( $p 80)$ is approximately $25 \mu \mathrm{m}$ [7].

The flotation of itabirite iron ore slimes, without prior classification, is not yet adopted in any industrial iron ore plant due to some problems related to the characteristics of the slimes and to equipment limitations. In recent years, research aimed at concentrating ultrafine particles by flotation has received greater importance. Improvements in equipment, such as the use of microbubbles in column flotation and the studies of new, more selective reagents, aim to contribute to the development of processes for iron ore slimes concentration by flotation.

\subsection{Equipment Improvements for Ultrafines Flotation-Microbubbles}

Trahar [10] investigated the relationship between particle size and flotation efficiency. In summary, the author stated that the collision efficiency is a function of particle size, and the adhesion efficiency depends on the mineral hydrophobicity degree and particle size. The collision and the adhesion efficiency increase with the hydrophobicity degree and decreases with particle size. The flotation of ultrafine particles may be improved by increasing the collision rate; thus, the flotation rate may be increased by enhanced aggregation, using smaller bubbles, increased residence time in the machine and providing countercurrent flows of particles and bubbles [11]. Flotation of very fine and large particles is facilitated with small bubbles [12].

Farrokhpay et al. [13] studied how microbubbles interact with fine quartz particles and facilitate the flotation of these particles in a conventional flotation system and as stated by the authors, the higher quartz flotation rate obtained in the presence of microbubbles can be attributed to a higher attachment efficiency of conventional bubbles with particles coated with microbubbles.

In the studies carried out by Oliveira et al. [14], the cavitation tube produced bubbles in a bimodal distribution, with a wide size range at the nano and micro scales, providing air holdup values as high as $16 \%$, a bubble surface area flux $S_{b}$ of $85 \mathrm{~s}^{-1}$ and a very high concentration of nanobubbles (Sauter mean diameter $=230-280 \mathrm{~nm}$ ) of $6.4 \times 10^{8} \mathrm{NBs} \cdot \mathrm{mL}^{-1}$. According to Fan et al. [15], the application of the cavitation tube system for upgrading of fine and ultrafine phosphate ore in Brazil proved successful and makes it possible to extend the size range of particles that could be treated by flotation to $5-10 \mu \mathrm{m}$ (originally, cut-size of the desliming stage at this plant was $25-30 \mu \mathrm{m}$ ).

\subsection{Developments of Collectors Regarding the Brazilian Iron Ores Slimes Characteristics}

Regarding Brazilian iron ore processing plants, the typical flotation feed consists of particles in the size range between $10 \mu \mathrm{m}$ and $300 \mu \mathrm{m}$ and the desliming process is carried out by hydrocyclones [16]; thus, the Fe content in the Brazilian slimes is high in comparison to the slimes produced by the selective flocculation process.

Slimes samples were collected at 21 points in the tailings dam of Fundão, at the Samarco Mining, in the Iron Quadrangle, Brazil by Lima and Abreu [17], and they found that the main minerals detected were goethite, hematite, quartz, and kaolinite. Pure kaolinite is constituted by $39.5 \%$ of $\mathrm{Al}_{2} \mathrm{O}_{3}$ and $46.55 \%$ of $\mathrm{SiO}_{2}$ and the reverse cationic flotation route is less selective for the separation between alumina/hematite than for quartz/hematite [18]. The particles size distribution of clay minerals, such as kaolinite, is 
also another issue regarding the flotation process; fine particles typically show slow recovery rates, owing to decreased particle-bubble collisions, and are prone to entrainment [19].

According to Ma and Bruckard [20], starch-kaolinite interactions are critically important for the successful removal of kaolinite from iron ore in selective flocculation and froth flotation processes. Ma et al. reported that the selective depression of hematite against kaolinite largely depends on strict $\mathrm{pH}$ control in iron ore flotation circuits and the level of ionic strength in pulp $[18,20]$.

Nykänena et al. [21] studied the loss of iron-bearing minerals to the froth in two industrial mechanical flotation circuits (Conceição Itabiritos II and Pico). There are two mechanisms for this iron mineral loss, especially in the finer fractions $(-44 \mu \mathrm{m})$ : hydrodynamic dragging and true flotation and, according to the authors, at Conceição Itabiritos II, concerning the particles size below $44 \mu \mathrm{m}, 65.4 \%$ of the iron in this fraction was carried to the froth due to due inefficiency in the depression process. Thus, the adoption of a selective collector, without the need for the use of a depressant reagent, will contribute to the improvement of the metallurgical recovery of ultrafine particle flotation.

According to the studies performed by Filippov et al., Fe-Mg-Al-bearing silicates may form strong chemical complexes with starch molecules used as iron oxide depressants due to the presence of metal ions on the mineral surface [22-25]. Thus, the use of starch as a depressant in the reverse flotation containing deleterious minerals, as in some iron ore slimes, can reduce the selectivity of the process.

Recently, differently structured amines (modified amines or polyamines, amideamines alone or mixed with ether amines, alkyl phosphonium) has drawn great attention in the field of reverse iron ore flotation [26]. Concerning Brazilian iron ore, recent studies [27] demonstrated the possibility of adopting a specific amidoamine type collector as a new collector reagent for reverse iron ore slimes flotation. The main advantage of this reagent is its high selectivity, eliminating the use of starch or other types of depressants. The authors carried out slime flotation studies with single particular sample from the Iron Quadrangle region using the amidoamine Flotinor 5530 as a collector in the absence of a depressant. It was possible to obtain, using one rougher flotation stage, a product with iron content above $60 \%$ and Fe recovery above $90 \%$ for one sample tested.

The main active molecule of the Flotinor 5530 collector is amidoamine N-[3(Dimethylamino)propyl]dodecanamide. Silva et al. [28] performed fundamental study with this amidoamine molecule and demonstrated its high selectivity by contact angle measurements and bench scale flotation tests. The increased volume of the amidoamine polar head group compared to the conventional cationic collectors like etheramine makes this molecule more susceptible to steric hindrance effects and defines the selective adsorption on the silicate minerals confirmed by the Fourier-transform infrared spectroscopy (FTIR) [28]. This difference in adsorption behavior is responsible for the selective and total flotation of the quartz.

On the other hand, the flotation behavior of kaolinite is similar to that of hematite, while the FTIR analysis showed a spectral profile similar to the quartz spectrum. In this case, the high specific surface area of kaolinite, coupled to its double-sheet structure may be an explanation for this behavior $[19,20]$. According to Silva et al., the most adequate hypothesis for the mechanism responsible for this selective flotation is a hindrance effect due to intermolecular interactions, such as molecular arrangements or interactions promoted by hydrogen bonds and/or electrostatic forces [28].

The main difference between the studies carried out by Matiolo and this present work is that they used only one slimes sample to carry out a series of flotation tests on small diameter pilot columns ( 2 and 6 inches). Therefore, the effect of the variability of slime characteristics due to the industrial process was not considered.

\subsection{Objectives of This Paper}

This paper presents the results of the continuous pilot campaign of reverse cationic flotation of the iron ore slimes (rougher stage) combining column flotation and a new collector 
reagent avoiding the use of a depressant, showing the fluctuation of some slimes characteristics (such as iron content and percentage of solids) in an industrial plant and discussing the effect of some operational parameters on the iron ore slime flotation performances.

The operation parameters of the column (air rate, carrying capacity, wash water rate) and the reagent dosage were evaluated based on the collected data on the $\mathrm{Fe}, \mathrm{SiO}_{2}, \mathrm{Al}_{2} \mathrm{O}_{3}$ contents in the concentrate. The need to implement automatic control systems for parameters such as collector dosage, washing water and air flow is discussed regarding an eventual industrial application of column flotation as rougher stage in a slime concentration process.

\section{Materials and Methods}

\subsection{Industrial Plant}

The pilot tests were carried out at Vargem Grande 2 iron ore processing plant, located in the Iron Quadrangle (IQ) in Minas Gerais, Brazil. The plant was designed to concentrate 22.36 million tons per year of ROM (run of mine) with the objective of producing concentrates with silica content ranging from $1.5 \%$ to $2.5 \%$.

The industrial process route (Figure 1) basically consists of four crushing stages to reduce the run of mine (ROM) until d95 at $16 \mathrm{~mm}$; the crushed ore is sent to a homogenization pile, where is reclaimed to feed four ball mills ( $4000 \mathrm{kw}$ per mill) working in a closed circuit with 26 inches hydrocyclones. The product of the grinding stage (d95 at $0.15 \mathrm{~mm})$ feeds the desliming circuit that consists of two stages (20 and 10 inch hydrocyclones). The underflow of the desliming circuit feeds the conditioner, where the starch is dosed. After the conditioning stage, the pulp feeds the conventional tank cell flotation circuit, where the amine is dosed as collector at $\mathrm{pH}$ 9.8-10.2. The concentrate feeds a thickener (diameter of $40 \mathrm{~m}$ ) and its underflow is filtered by disc filters. The froth containing the non-valuable minerals is disposed to the tailings dam.

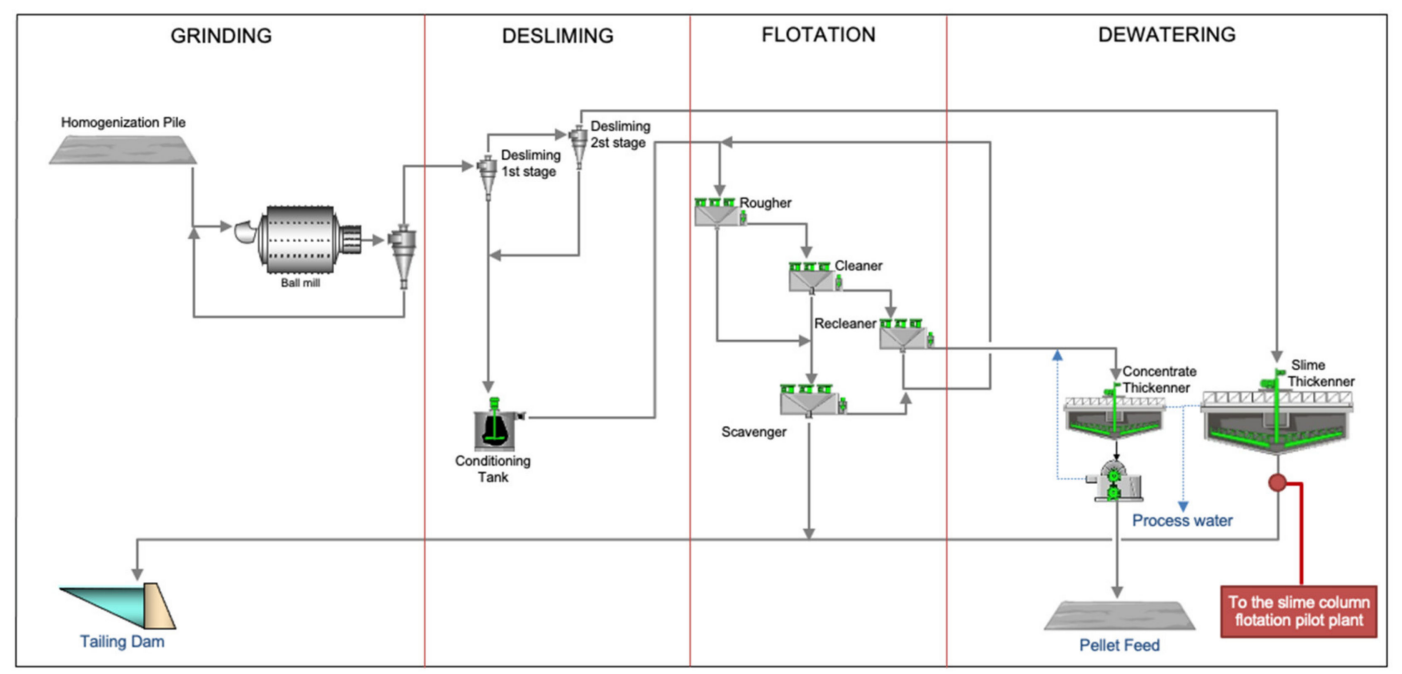

Figure 1. Simplified flowsheet of Vargem Grande 2 industrial plant.

The slime (overflow of second desliming stage-10 inch hydrocyclones) feeds the slime thickener (diameter $100 \mathrm{~m}$ ). The underflow of the slime thickener is sent to the tailings dam.

\subsection{Pilot Plant}

The pilot plant was constructed close to the slimes thickener and part of the stream from the thickener underflow was diverted towards this plant.

The tests were performed using a pilot flotation column of $500 \mathrm{~mm}$ diameter and $4000 \mathrm{~mm}$ height with a cavitation tube system for bubbles generation. The device consists of a centrifugal recycle pump with a sparger designed to induce cavitation and generate 
fine bubbles. A portion of the slurry underflow is drawn from the column and pumped to a cavitation tube sparger where the air is injected under pressure. The pilot plant flowsheet is shown in Figure 2.

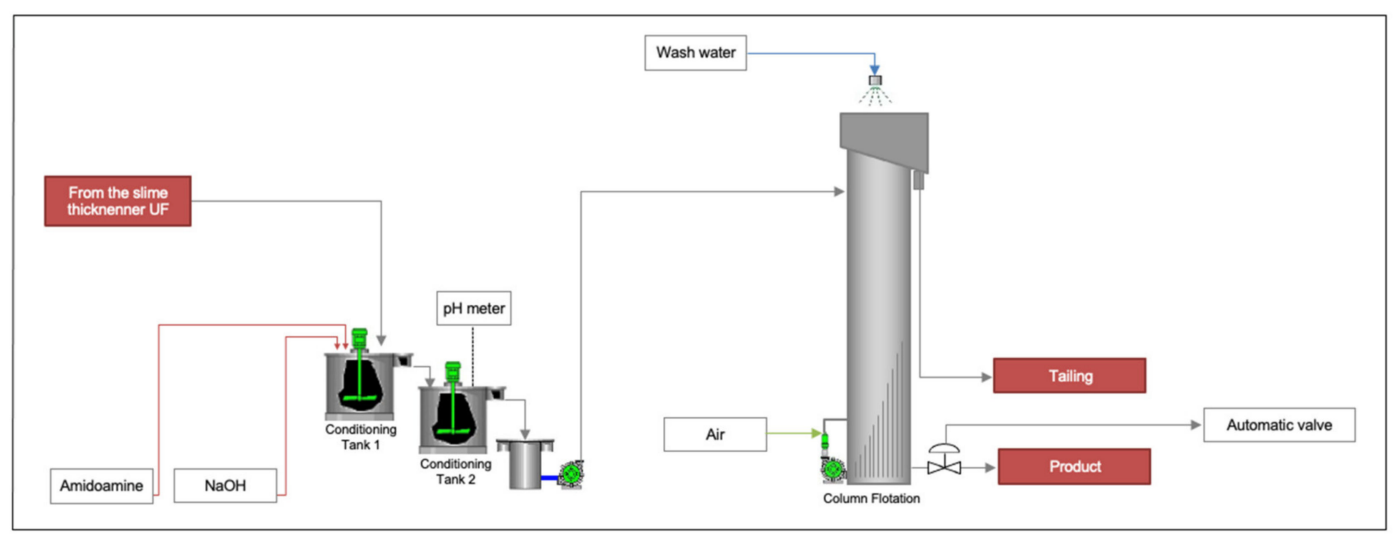

Figure 2. Pilot plant flowsheet.

\subsection{Reagents}

Information regarding the reagents is summarized in Table 1.

Table 1. Summary of all the reagents used in the experimental work.

\begin{tabular}{ccc}
\hline Name & Type of Reagent/Role & Comments: \\
\hline Flotinor 5530 & Collector & Amidoamine \\
Sodium hydroxide & pH Modifier & - \\
\hline
\end{tabular}

The amidoamine type collector Flotinor 5530 (Clariant, Belo Horizonte, Brazil), whose main active molecule is N-[3-(Dimethylamino)propyl]dodecanamide, was not adopted yet in the industrial iron ore flotation process and previous studies demonstrated that its application for the slimes flotation similar to the slimes from Vargem Grande 2 does not require a depressant [27].

\subsection{Characterization}

The chemical analyses were carried out by X-ray fluorescence at Vale's chemical analytical laboratories.

Wet sieving was used to minimize the loss of fine particles in dust form and to reduce minerals agglomeration in the slimes sample. A total of six size classes were chosen: $>106$, 106-80, 80-40, 20-10 and $>10 \mu \mathrm{m}$.

The mineral phases were identified by X-ray diffraction using a Bruker AXS diffractometer.

\subsection{Operational Parameters of Flotation Column}

The superficial velocity (expressed in $\mathrm{cm} \cdot \mathrm{s}^{-1}$ ) is the ratio of the volumetric flow rate to the column cross-section.

Superficial feed velocity, for example, determines the column flotation results. It defines the value of the following parameters:

1. Slurry residence time

2. Liquid velocity

3. Bubble rise velocity 
In this paper, the superficial velocity of solids $\left(J_{S}\right)$, water $\left(J_{L}\right)$, slurry $\left(J_{S L}\right)$ to the product, tailings and feed and the superficial velocity of washing water $\left(\mathrm{J}_{W}\right)$ was calculated. As the studies refer to the reverse flotation of iron ore, the tailing is the froth (floated) product.

Due to the countercurrent nature of the flows, air bubbles (or particle/bubble aggregates) should exceed a certain velocity to reach the froth otherwise they will report to tailings. This limits the utilization of fine bubbles.

The gas phase is also characterized by the superficial gas (air) velocity $\left(J_{g}\right)$.

The effect of the air flow rate on flotation performance at a constant feed flow has a complex nature. Increased superficial air velocity causes a raise in the gas holdup and in the average bubble size due to the bubble coalescence. The bubble surface area defines bubble carrying capacity while increased bubble diameter reduces the collision probability.

An American Platinum Bubble Sizer (APBS) was adopted to measure the size of the bubbles (Sauter diameter- $d_{3.2}$ ) and the superficial gas velocity $\left(J_{g}\right)$.

\section{Results}

\subsection{Sample Characterization}

Table 2 shows the chemical analysis of a typical slimes sample from the industrial plant.

Table 2. Chemical analysis of the slimes sample.

\begin{tabular}{cccccc}
\hline ID & $\mathbf{F e}$ & $\mathbf{S i O}_{\mathbf{2}}$ & $\mathbf{A l}_{\mathbf{2}} \mathbf{O}_{\mathbf{3}}$ & $\mathbf{P}$ & Loss on ignition (LOI) \\
\hline Slimes Flotation Feed & 44.31 & 31.09 & 2.85 & 0.079 & 2.15 \\
\hline
\end{tabular}

The particles size analysis of this typical slime sample is presented in Figure 3. The results show that $83 \%$ of the total mass consists of particles below $20 \mu \mathrm{m}, 3 \%$ above $106 \mu \mathrm{m}$, and $14 \%$ between 20 and $106 \mu \mathrm{m}$.

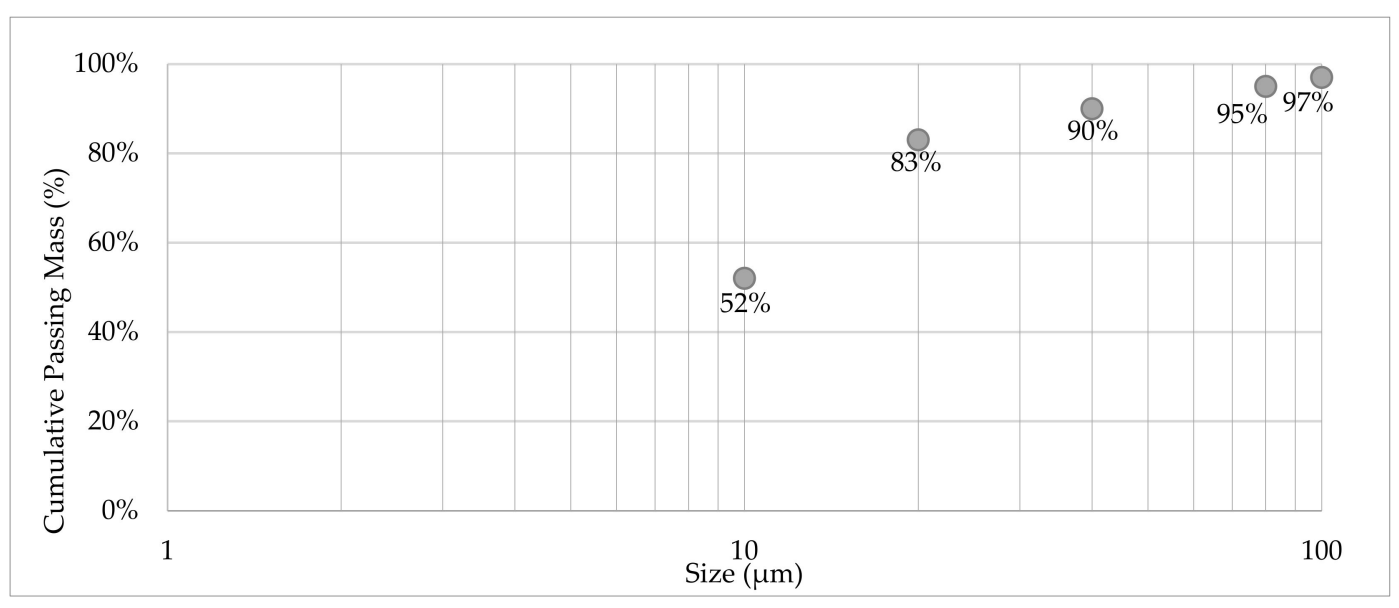

Figure 3. Particle size distribution of the slime sample.

Ma et al. [29] stated that the reverse cationic flotation tends to display unsatisfactory results for such fine-grain particles.

Figure 4 presents the element distribution by size fraction of this typical slimes sample. The majority of the iron $(87 \%)$ is present in the fine particle size fractions $(<20 \mu \mathrm{m})$. The presence of $\mathrm{Fe}$ in the fine fraction is problematic when aiming to achieve an efficient separation by reverse cationic flotation since fine hematite particles are susceptible to report to the froth product (tailings). 


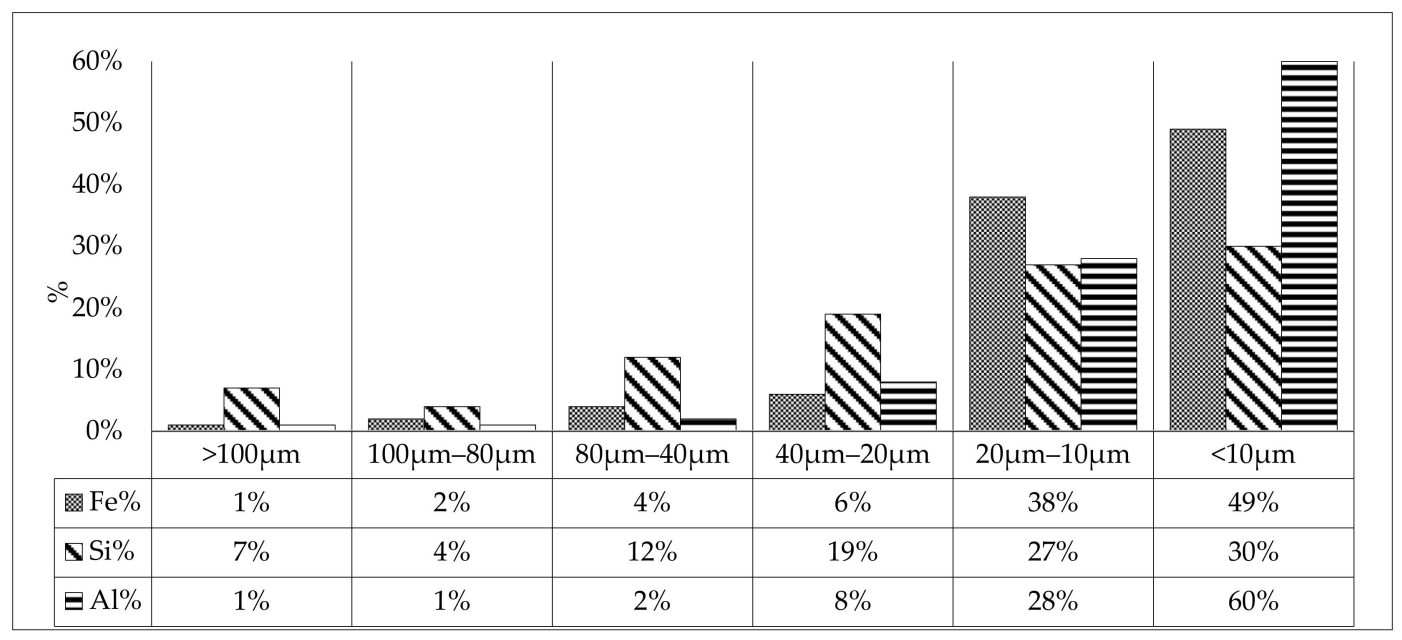

Figure 4. Fe, $\mathrm{Si}$ and $\mathrm{Al}$ in feed according to size fractions.

An important issue regarding this element distribution by size fraction is that in literature, it is often found that desliming is performed at $10 \mu \mathrm{m}$ to obtain a good separation efficiency in the flotation process [30]. However, as previously stated, if the current sample is deslimed at $10 \mu \mathrm{m}$, approximately $49 \%$ of the total iron content will be lost.

XRD analysis was performed on the six size classes. A summary of the identified minerals and the corresponding size classes is displayed in Table 3.

Table 3. Summary of the identified minerals present in the slimes sample via XRD by different size classes.

\begin{tabular}{cc}
\hline Size Class $(\boldsymbol{\mu m})$ & Minerals Identified \\
\hline$>106$ & Hematite + Goethite + Quartz + Kaolinite + Muscovite \\
$106-80$ & Hematite + Quartz + Kaolinite \\
$80-40$ & Hematite + Goethite + Quartz + Kaolinite + Muscovite \\
$40-20$ & Hematite + Goethite + Quartz + Kaolinite + Muscovite, \\
Chlorite & Hematite + Goethite + Quartz + Kaolinite + Muscovite, \\
$10-20$ & Chlorite \\
$10-0$ & Hematite + Goethite + Quartz + Kaolinite + Muscovite \\
\hline
\end{tabular}

Figure 5 shows the typical mineralogical composition of a slimes sample from the industrial plant.

Both quartz $\left(\mathrm{SiO}_{2}\right)$ and kaolinite $\left(\mathrm{Al}_{4}\left(\mathrm{Si}_{4} \mathrm{O}_{10}\right)(\mathrm{OH})_{8}\right)$ are common gangue minerals associated with iron oxide slimes, while hematite and goethite are the main iron minerals. Depending on the goethite type, its presence could be problematic regarding the silica content in the concentrate. Goethite has three common forms, including brown, yellow ochreous and dark brown. The yellow ochreous is reported to contain considerable amounts of $\mathrm{Al}_{2} \mathrm{O}_{3}$ and $\mathrm{SiO}_{2}(2-9 \%)$. It is still under debate if these impurities occur as inclusions in the goethite mineral or if it occurs by elemental substitution of Al in Si into the crystal lattice [31]. The presence of these impurities can cause selectivity problems in the reverse cationic flotation since the amines can adsorb onto the goethite. Moreover, the flotation does not provide successful removal of these impurities [32].

Figure 6 shows a selected SEM image for the slimes sample (Magnification: $500 \times$ ) and the elemental mapping performed. Based on the EDS analysis, it is possible to state that in Figure $6 a$ the white color particles represent hematite minerals, while the grey particles represent quartz. In the high-resolution elemental map (Figure 6b), Fe is represented by the red color, and $\mathrm{Si}$ is represented with the green color. 


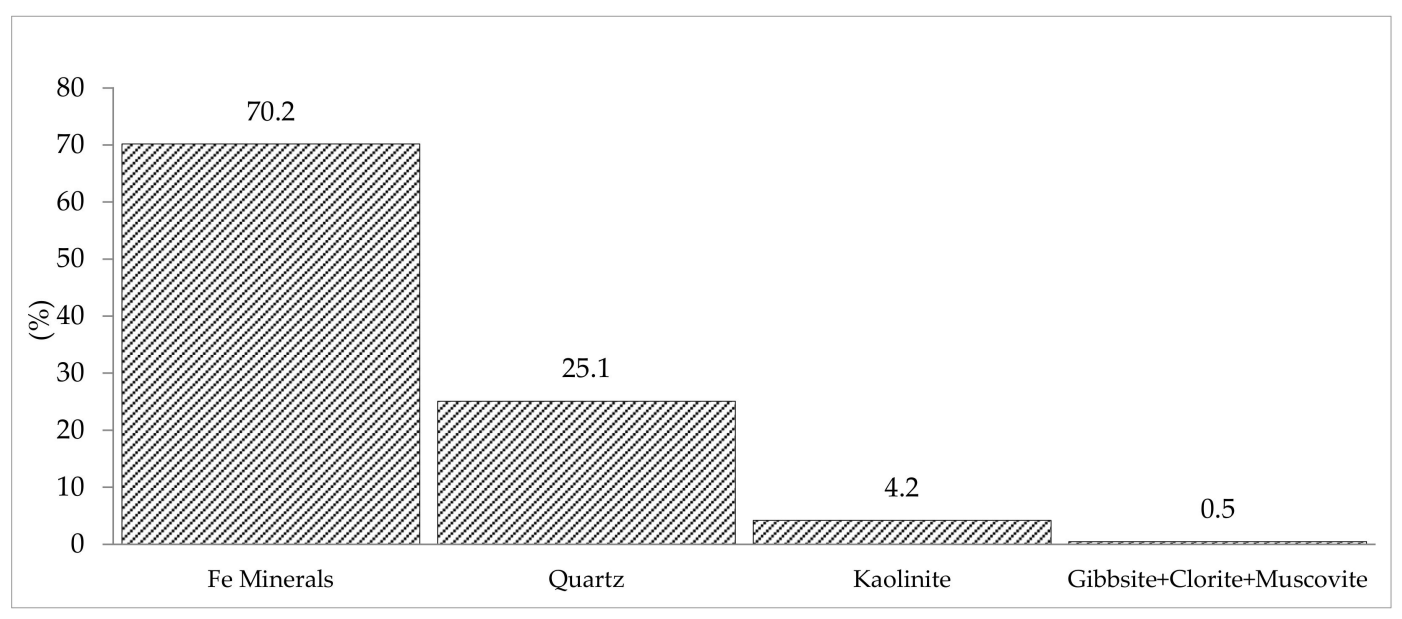

Figure 5. Typical mineralogical composition of a slimes sample from the industrial plant studied.

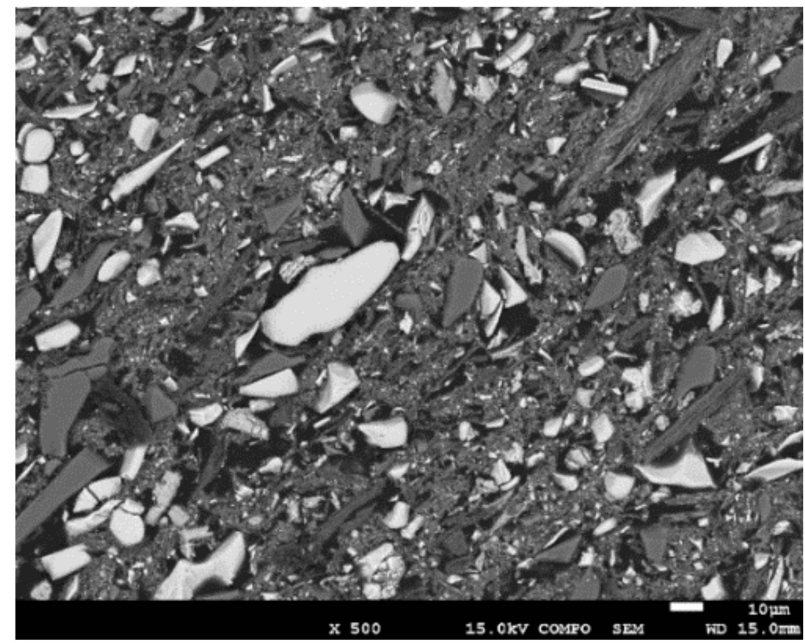

(a)

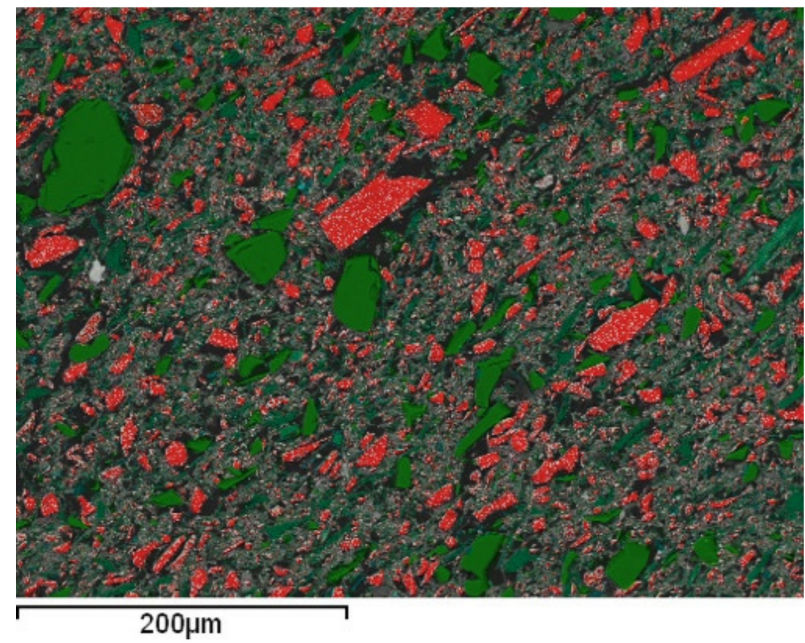

(b)

Figure 6. (a) Selected SEM image (500× magnification); (b) X-ray elemental mapping image (500× magnification).

It is also notable the considerable presence of a very fine grain of hematite (iron oxides) in the smaller size fractions $(<10 \mu \mathrm{m})$. This observation reinforces the statements made previously that desliming the sample at $10 \mu \mathrm{m}$ would result in a significant loss of iron.

\subsection{Pilot Flotation General Conditions}

Amidoamine Flotinor 5530 was used as a collector at a dosage of $152-160 \mathrm{~g} / \mathrm{t}$ in the absence of depressant. The flotation was performed in a 500-mm column at $\mathrm{pH} 10.5$.

The flotation conditions in the pilot tests presented in this work were set to mimic the parameters ( $\mathrm{pH}$ and collector dosage) reported by Matiolo [27], where the iron ore slimes flotation was performed in a 2"and 6" column.

The measurements (Table 4 ) were performed to assess the hydrodynamic conditions of the flotation column during pilot tests at the Vargem Grande 2 site.

Table 4. Values obtained by the measurements carried out in the pilot column during the tests.

\begin{tabular}{cc}
\hline ID & Measured Value \\
\hline Superficial gas velocity $\left(J_{g}\right)$ & $1.94 \mathrm{~cm} \cdot \mathrm{s}^{-1}$ \\
Sauter diameter $\left(d_{3.2}\right)$ & $0.92 \mathrm{~mm}$ \\
\hline
\end{tabular}




\subsection{Variability of the Slimes in the Industrial Plant}

According to Trahar and Warren [33], the overall flotation performance deteriorates for the finer particles, but the precise effects of particle size on recovery, grade, and flotation rate are supposed to be more complex. Regarding the pilot tests in line with the industrial plant, several factors can contribute to low $\mathrm{SiO}_{2}$ recovery to the froth in some tests, such as collector dosage per $\mathrm{SiO}_{2}$ content in the feed, washing water and industrial plant operation variations (i.e., grinding parameters, as $p 80$ ). Issues related to mineralogy and mineral particles liberation must also be considered.

Figures $7-10$ show the variability of the $\% \mathrm{SiO}_{2}, \% \mathrm{Fe}, \% \mathrm{Al}_{2} \mathrm{O}_{3}$ and $\%$ solids in the flotation feed (underflow of the industrial thickener) during 67 pilot tests.

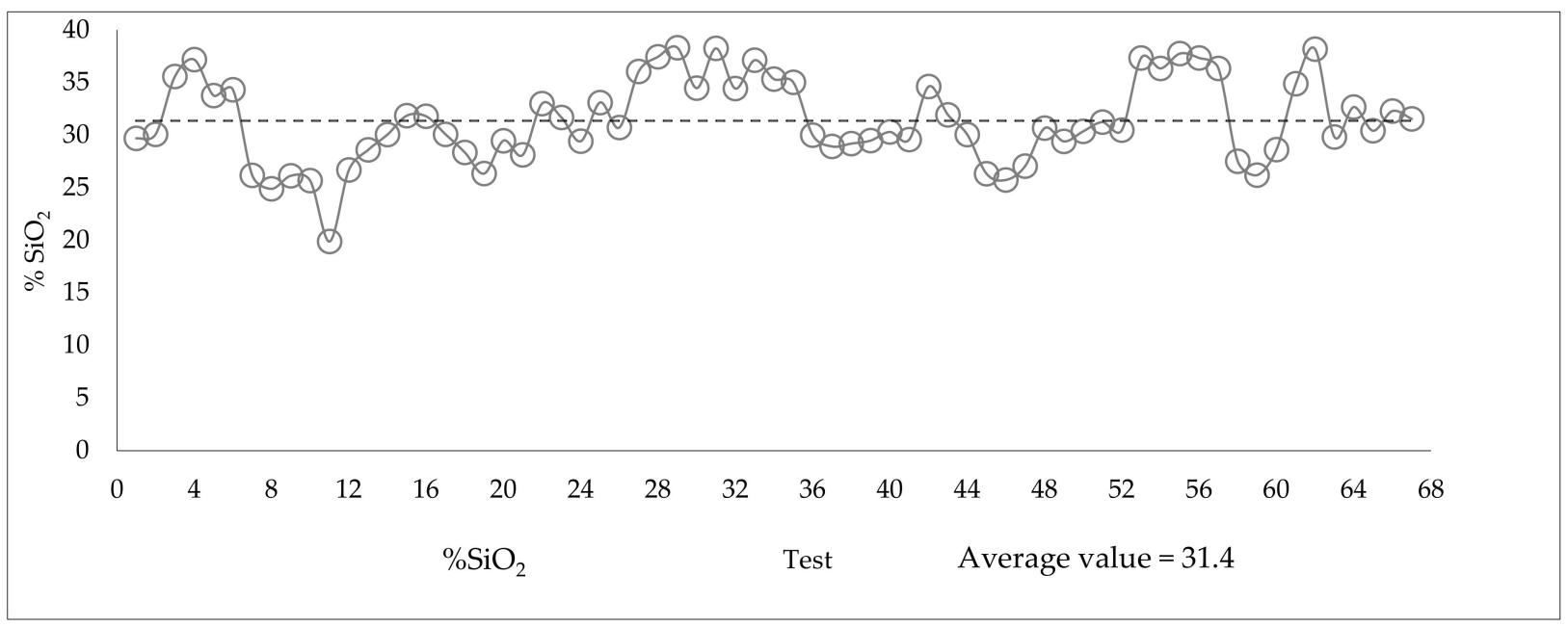

Figure 7. Variation of values concerning the $\mathrm{SiO}_{2}$ content in the flotation feed during the pilot tests.

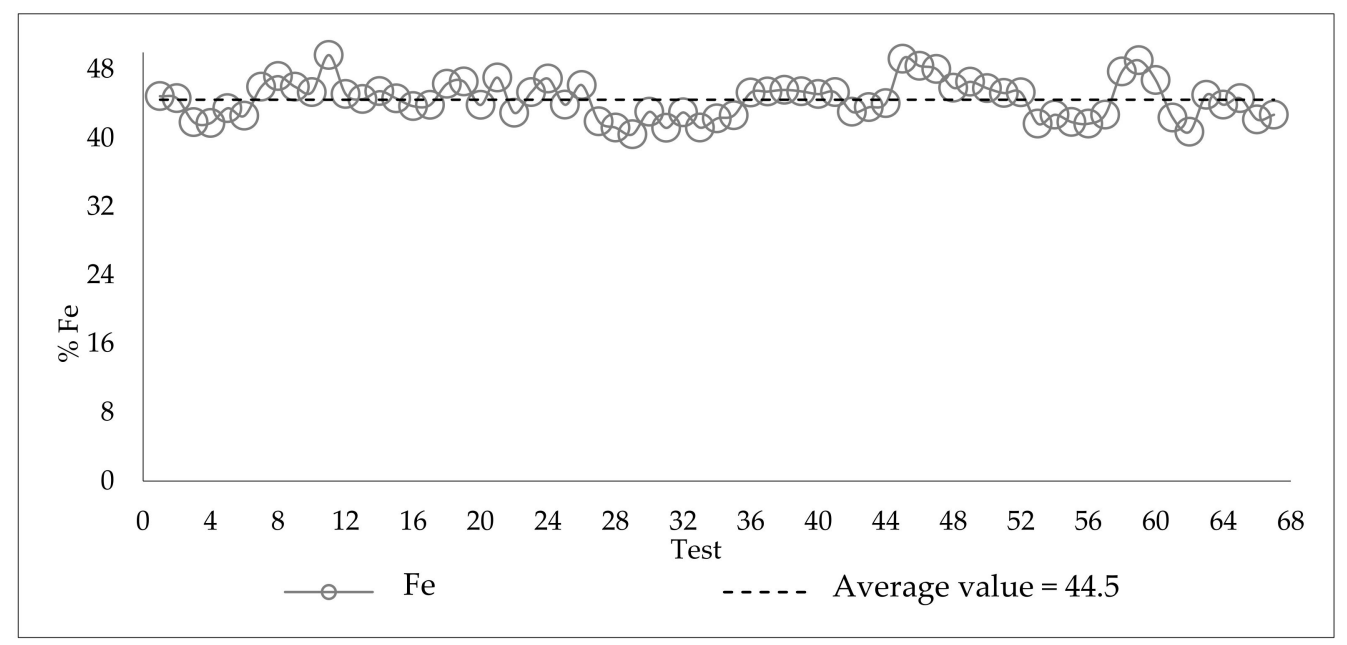

Figure 8. Variation of values concerning the Fe content in the flotation feed during the pilot tests. 


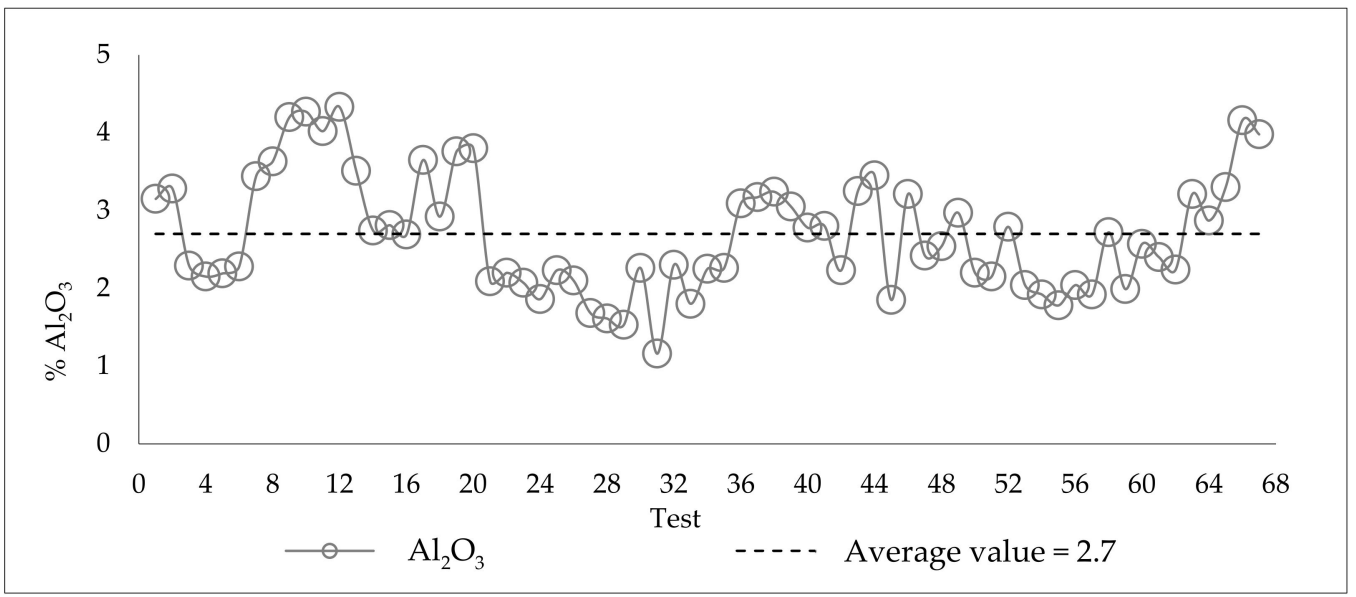

Figure 9. Variation of values concerning the $\mathrm{Al}_{2} \mathrm{O}_{3}$ content in the flotation feed during the pilot tests.

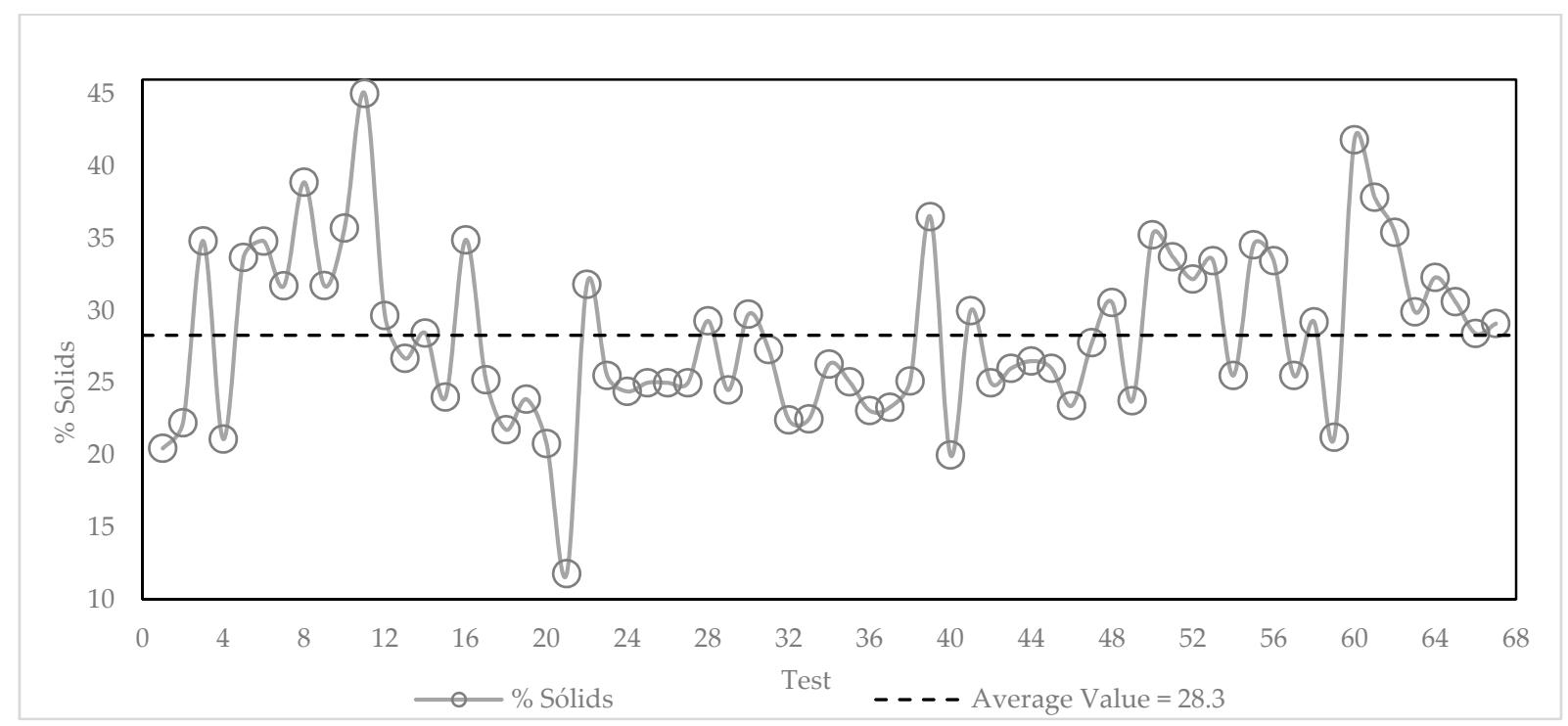

Figure 10. Variation of values concerning the percentage of solids in the flotation feed during the pilot tests.

The high variability in slimes characteristics can be explained by operational factors in the plant. The iron ore slimes are a reject fraction of the process, which is disposed of in the tailings dam. Therefore, regarding the slimes, the operational control of the plant aims to obtain the maximum percentage of solids in the slimes thickener underflow (provided that the quality of the overflow water is in accordance with the specifications of the industrial process water) and to reduce the amount of the slimes generated in the grinding and desliming process, since that the iron content in the final product and the metallurgical recovery of conventional flotation are maintained within acceptable values or even optimized.

Concerning the mining planning, in some cases, the mineralogical knowledge linked to the genesis of the ore may not be useful to predict the mineral processing responses in the industrial plant. For example, the mineralogy of the ore genesis identifies the presence of goethite, but it does not classify this mineral in terms of its chemical composition, such as aluminous goethite and siliceous goethite [34].

\subsection{Initial Pilot Flotation Tests—Summary Results for a 6-Day Test Period}

Considering the high variability of the slime characteristics, a six-day test period was selected in May 2018 to analyze the detailed results regarding the efficiency of the collector amidoamine in iron ore slimes flotation in the absence of a depressant. The objective of 
choosing a specific period was to reduce possible interferences in the pilot flotation results due to natural slime variations in the plant.

Results reported by Matiolo et al. [27] adopted a singular sample to carry out pilot slime flotation column tests using the amidoamine Flotinor 5530 as a collector without starch, where it was possible to achieve iron grades of approximately $62 \%$ in the concentrate and $8 \%$ in the tailings; however, there are no concentration plants by flotation for itabirite iron ore consisting of one single stage. As an example, Figure 1 shows that the industrial flowsheet for the flotation of the deslimed iron ore from the Vargem Grande 2 plant consists of four stages: rougher, cleaner, recleaner and scavenger.

Therefore, the results presented need to be evaluated at the first slime concentration stage where the product could feed a cleaner stage or even the conventional flotation circuit. Eventually, depending on the product obtained in the first stage, a cleaner stage can be bypassed, and the rougher product can be combined with the conventional pellet feed.

Table 5 shows the results concerning the period of 9-16 May 2018. The average parameters adopted during these tests were: collector dosage $160 \mathrm{~g} / \mathrm{ton}$, absence of starch, $\mathrm{pH}$ 10.5, froth height of $15 \mathrm{~cm}$, and an average collector conditioning time of $10 \mathrm{~min}$.

Table 5. Results of the pilot tests from 9 to 16 May 2018.

\begin{tabular}{|c|c|c|c|c|c|c|c|c|c|c|c|}
\hline \multirow{2}{*}{ Test } & \multirow{2}{*}{ ID } & \multirow{2}{*}{ Mass (kg/h) } & \multirow{2}{*}{$\%$ Solids } & \multirow{2}{*}{$\begin{array}{c}\text { Flowrate } \\
(1 / h)\end{array}$} & \multirow{2}{*}{ Water $(1 / \mathrm{h})$} & \multicolumn{6}{|c|}{ Grade (\%) } \\
\hline & & & & & & $\mathrm{Fe}$ & $\mathrm{SiO}_{2}$ & $\mathrm{Al}_{2} \mathrm{O}_{3}$ & $\mathbf{P}$ & Mn & LOI \\
\hline \multirow{4}{*}{ 09/may } & Feed & 660 & 32.0 & 1582 & 1403 & 44.6 & 31.9 & 2.4 & 0.08 & 0.03 & 1.8 \\
\hline & Product & 552 & 14.2 & 3490 & 3349 & 50.5 & 23.7 & 2.1 & 0.10 & 0.04 & 1.8 \\
\hline & Tailings & 108 & 15.4 & 632 & 593 & 14.3 & 74.1 & 3.8 & 0.02 & 0.01 & 1.6 \\
\hline & \multicolumn{2}{|c|}{ Washing water $(\mathrm{l} / \mathrm{h})$} & 2539 & \multicolumn{3}{|c|}{ Recovery Fe Product } & 94.8 & \multicolumn{3}{|c|}{ Recovery $\mathrm{SiO}_{2}$ Froth } & 37.9 \\
\hline \multirow{2}{*}{ Test } & \multirow{2}{*}{ ID } & \multirow{2}{*}{ Mass (kg/h) } & \multirow{2}{*}{$\%$ Solids } & \multirow{2}{*}{$\begin{array}{c}\text { Flowrate } \\
(1 / \mathrm{h})\end{array}$} & \multirow{2}{*}{ Water $(\mathbf{l} / \mathbf{h})$} & \multicolumn{6}{|c|}{ Grade (\%) } \\
\hline & & & & & & $\mathrm{Fe}$ & $\mathrm{SiO}_{2}$ & $\mathrm{Al}_{2} \mathrm{O}_{3}$ & $\mathbf{P}$ & Mn & LOI \\
\hline \multirow{4}{*}{ 10/may } & Feed & 640 & 31.2 & 1580 & 1412 & 47.5 & 28.9 & 1.7 & 0.06 & 0.01 & 1.4 \\
\hline & Product & 467 & 13.3 & 3141 & 3034 & 58.5 & 12.6 & 1.8 & 0.08 & 0.02 & 1.7 \\
\hline & Tailings & 174 & 26.8 & 535 & 475 & 17.7 & 72.4 & 1.5 & 0.01 & 0.01 & 0.7 \\
\hline & \multicolumn{2}{|c|}{ Washing water $(\mathrm{l} / \mathrm{h})$} & 2097 & \multicolumn{3}{|c|}{ Recovery Fe Product } & 89.9 & \multicolumn{3}{|c|}{ Recovery $\mathrm{SiO}_{2}$ Froth } & 68.1 \\
\hline \multirow{2}{*}{ Test } & \multirow{2}{*}{ ID } & \multirow{2}{*}{ Mass (kg/h) } & & Flowrate & W/n $-1 / b_{1}$ & & & Gra & & & \\
\hline & & & o Sollas & (1/h) & Water (I/n) & $\mathrm{Fe}$ & $\mathrm{SiO}_{2}$ & $\mathrm{Al}_{2} \mathrm{O}_{3}$ & $\mathbf{P}$ & Mn & LOI \\
\hline & Feed & 505 & 26.1 & 1565 & 1433 & 48.2 & 25.6 & 3.2 & 0.07 & 0.02 & 2.0 \\
\hline & Product & 382 & 21.5 & 1485 & 1394 & 56.5 & 14.1 & 2.8 & 0.08 & 0.03 & 2.0 \\
\hline 11/may & Tailings & 123 & 25.0 & 411 & 370 & 22.6 & 61.2 & 4.4 & 0.03 & 0.01 & 2.1 \\
\hline & Washin & ater $(1 / h)$ & 331 & & rery Fe Produ & & 88.6 & & $\mathrm{ry} \mathrm{SiO}$ & & 58.3 \\
\hline & & & & Flowrate & & & & Gra & & & \\
\hline Test & ID & IVlass (kg/n) & \% Solids & $(\mathbf{l} / \mathrm{h})$ & Water (I/h) & $\mathrm{Fe}$ & $\mathrm{SiO}_{2}$ & $\mathrm{Al}_{2} \mathrm{O}_{3}$ & $\mathbf{P}$ & Mn & LOI \\
\hline & Feed & 430 & 23.4 & 1519 & 1407 & 48.2 & 27.0 & 2.4 & 0.06 & 0.04 & 1.5 \\
\hline & Product & 282 & 16.1 & 1528 & 1465 & 61.1 & 8.8 & 2.0 & 0.08 & 0.05 & 1.7 \\
\hline 14/may & Tailings & 148 & 19.5 & 661 & 611 & 23.7 & 61.8 & 3.2 & 0.03 & 0.02 & 1.1 \\
\hline & Washin & ater $(1 / h)$ & 669 & & ery Fe Produ & & 83.1 & & $\mathrm{ry} \mathrm{SiO}$ & & 78.8 \\
\hline Toct & $\mathbf{D}$ & Masc $(k \sigma / h)$ & $0 /$ colide & Flowrate & W/an (1) & & & Gra & & & \\
\hline lest & ID & Indss (Kg/n) & \% Solids & (l/h) & Water (1/n) & $\mathbf{F e}$ & $\mathrm{SiO}_{2}$ & $\mathrm{Al}_{2} \mathrm{O}_{3}$ & $\mathbf{P}$ & Mn & LOI \\
\hline & Feed & 507 & 27.8 & 1449 & 1319 & 49.4 & 24.0 & 3.2 & 0.06 & 0.01 & 2.0 \\
\hline & Product & 403 & 16.6 & 2125 & 2030 & 57.1 & 13.4 & 2.8 & 0.07 & 0.01 & 2.0 \\
\hline 15/may & Tailings & 104 & 15.5 & 605 & 569 & 19.9 & 64.9 & 4.7 & 0.02 & 0.01 & 1.9 \\
\hline & Washin & ater $(1 / h)$ & 1280 & & ery Fe Produ & & 91.7 & & $\mathrm{ry} \mathrm{SiO}$ & & 55.5 \\
\hline & & & & Flowrate & & & & Gra & & & \\
\hline Test & ID & Mass (kg/h) & $\%$ Solids & $(1 / h)$ & Water $(\mathbf{l} / \mathrm{h})$ & $\mathrm{Fe}$ & $\mathrm{SiO}_{2}$ & $\mathrm{Al}_{2} \mathrm{O}_{3}$ & $\mathbf{P}$ & Mn & LOI \\
\hline & Feed & 600 & 30.6 & 1525 & 1364 & 45.6 & 30.5 & 2.5 & 0.05 & 0.01 & 1.6 \\
\hline & Product & 384 & 14.1 & 2422 & 2336 & 61.0 & 8.1 & 2.5 & 0.07 & 0.01 & 1.9 \\
\hline 16/may & Tailings & 216 & 23.8 & 766 & 691 & 18.2 & 70.2 & 2.6 & 0.01 & 0.01 & 1.1 \\
\hline & Washin & ater $(1 / h)$ & 1663 & & ery Fe Produ & & 85.7 & & $\mathrm{ry} \mathrm{SiO}$ & & 82.9 \\
\hline
\end{tabular}

Figures 11 and 12 show that it was possible to recover in the froth percentages of mass varying from $16.3 \%$ to $36.0 \%$, with an improvement in the iron content in the product varying from 5.9\% (May 9) to 15.4\% (May 16). The Figure 13 shows that, even the worst 
test result, carried out on May 9, recovered about $38 \%$ of all $\mathrm{SiO}_{2}$ in the froth, losing only $5.2 \%$ of the iron. The recovery of $\mathrm{SiO}_{2}$ reaches approximately $83 \%$, with a loss of $14 \%$ of iron in the best of case (May 14).

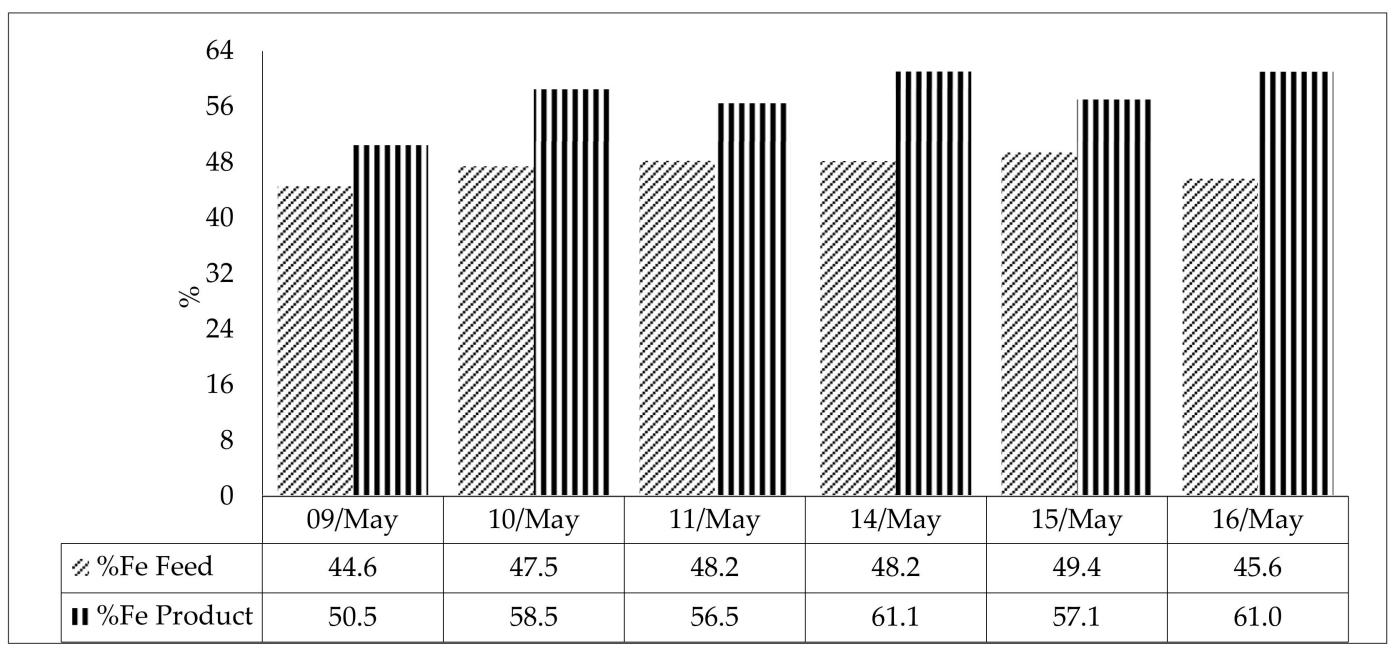

Figure 11. Fe content in feed and product.

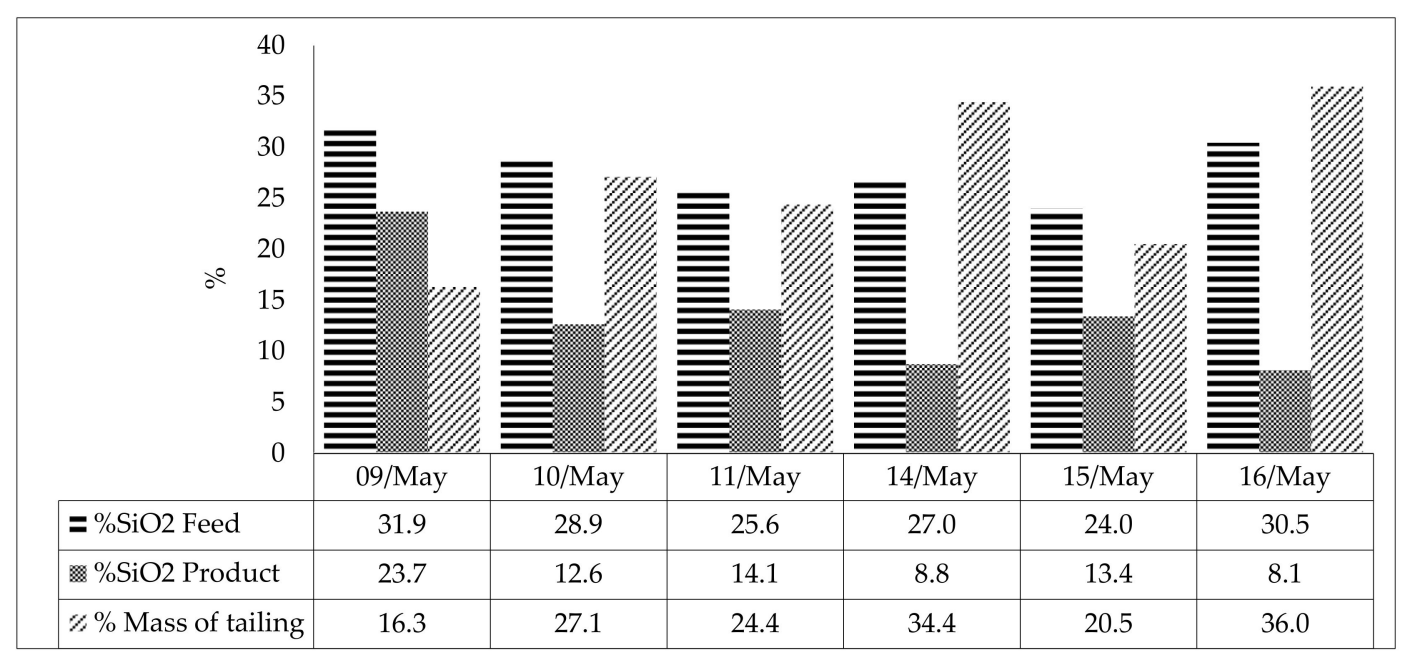

Figure 12. $\mathrm{SiO}_{2}$ content in the flotation feed and product; percentage of mass in the tailings.

Therefore, considering the losses of iron in comparison with the floated $\mathrm{SiO}_{2}$, the results show that this specific amidoamine collector could be adopted in slimes concentration since it provides a selective separation between ultrafine iron oxides and quartz (even in the absence of a depressant).

Some factors may have influenced the results regarding the variability of the $\mathrm{SiO} 2$ recovery values to froth. Concerning quartz, a hypothesis for this recovery values range is that there may have been variations in its particle size at each test, influencing the specific surface areas of this mineral, requiring a higher specific dosage of the reagent for sufficient hydrophobization of its surface in some cases. The probability of a collision in the flotation process may be also impaired by particle size variation [35]. This probability captured the attention of several researchers, who showed that this parameter is directly related to physical variables, such as particle size and bubble diameter [30].

The minimum degree of hydrophobicity necessary for the flotation of a particle depends on its size [10]. The low recovery of fine particles is often attributed to their low mass and inertia, which leads to the low probability of particle colliding with bubbles, as demonstrated by some authors [36]. Another reason for the low floatability of fine particles 
is that they possess insufficient kinetic energy (due to low mass) to displace the thin water film between the colliding particle and bubble and form the three-phase line of contact [37]. Scheludko et al. [38] has proposed the existence of a critical contact angle necessary for the flotation of fine particles. According to Chipfunhu et al. [37], the poor floatability of fine particles is mainly because they have not reached their critical contact angle.

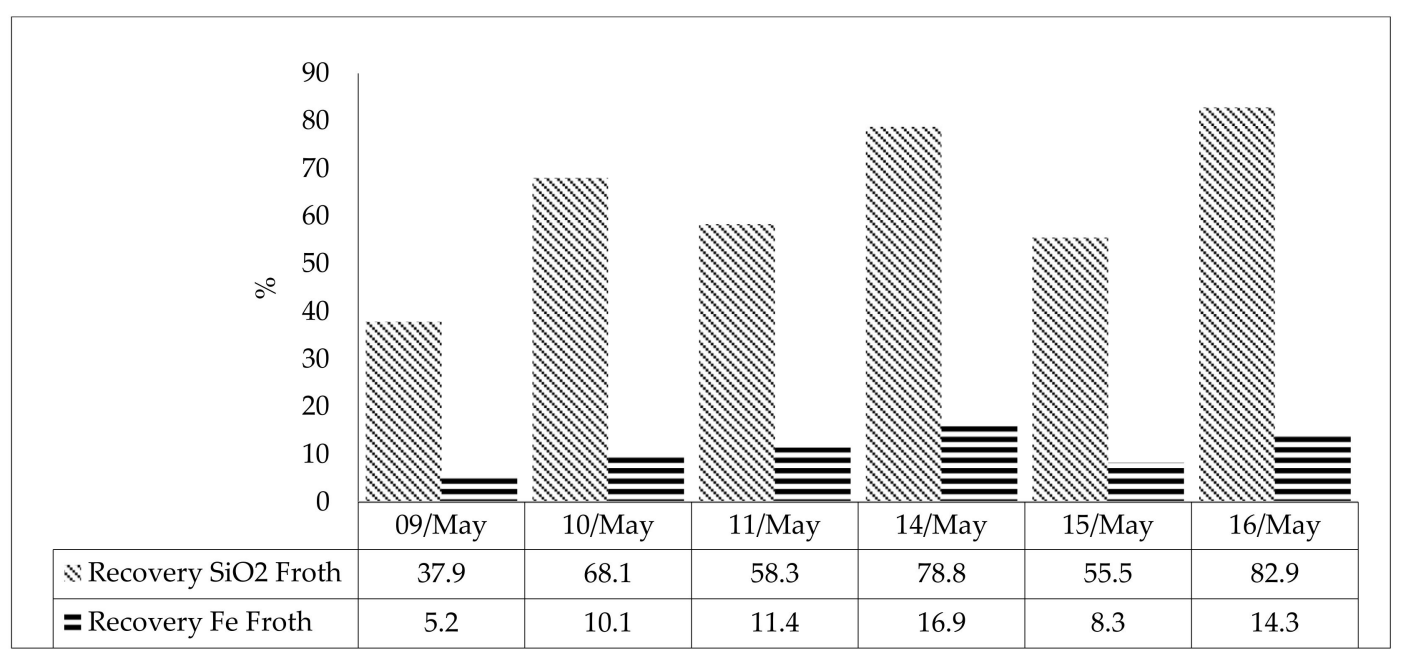

Figure 13. Recovery of $\mathrm{SiO}_{2}$ and $\mathrm{Fe}$ to the tailings.

Figure 5 demonstrated that the main alumina mineral in the slimes used in the pilot tests was kaolinite. The kaolinite structure has anisotropy, and this characteristic can explain its low recovery to froth in a flotation process. Souza et al. [39] showed that the application of amidoamine in kaolinite flotation in the beneficiation of manganese ore at acidic $\mathrm{pH}$ is feasible. However, according to $\mathrm{Xu}$ et al. [19], in the cationic flotation, the $\mathrm{pH}$ dependence of kaolinite flotation is the opposite to that of oxides with a lower flotation recovery obtained at higher $\mathrm{pH}$; therefore, the efficiency of kaolinite flotation using amidoamine is impaired at the $\mathrm{pH}$ adopted in the pilot tests (10.5). Kaolinite is a clay mineral; thus, the flotation of kaolinite is also impaired due to its small average size. Therefore, due to the issues regarding the kaolinite flotation, part of the $\mathrm{SiO}_{2}$ content in the product of the pilot tests may be originated from the kaolinite. The kaolinite may also represent a higher consumption of collector due to its greater specific surface, decreasing the collector available to adsorb on the quartz surface.

\subsection{Analysis of the Influence of Feed Variability and Operational Parameters on Flotation Results during the 67 Pilot Test Campaign}

\subsubsection{Results}

Figure 14 shows the variability of the iron content values in the feed, product, and tailings during 67 pilot rougher flotation tests. The operational parameters adopted in these tests are, on average, the same adopted on the pilot tests shown in Table 5.

Figure 15 shows the results concerning the $\mathrm{Fe}$ and $\mathrm{SiO}_{2}$ recoveries during the pilot tests.

The results presented in Table 6 shows that adopting only one slimes flotation stage (rougher), using the amidoamine Flotinor 5530 as a collector, in the absence of depressant, it was possible to float, on average, about $53.3 \%$ of $\mathrm{SiO}_{2}$ present in the slimes, yielding $\mathrm{Fe}$ recovery above $86.1 \%$ in $90 \%$ of the tests carried out (10th percentile).

Due to the high variability of the slime characteristics during the pilot tests, the values obtained from these tests were grouped by ranges aiming at the analysis of trends related to parameters concerning the flotation tests (Table 7). 


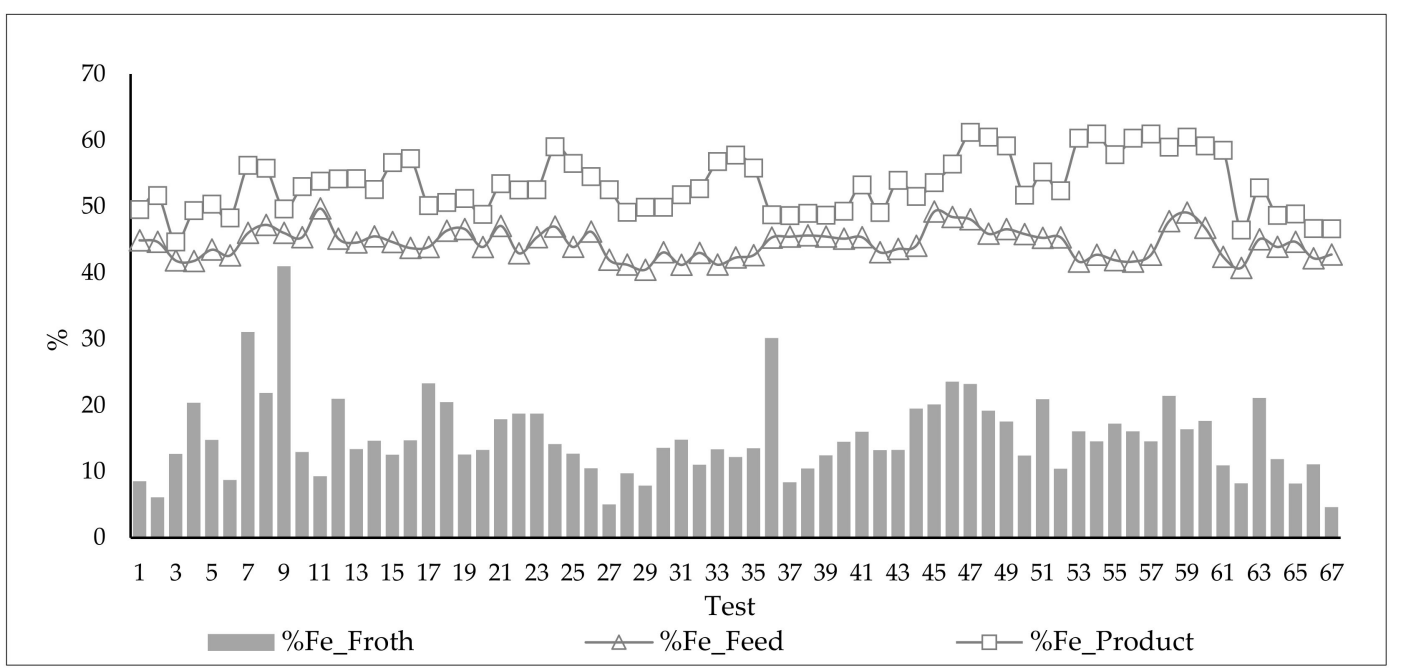

Figure 14. Results concerning the Fe content in the flotation feed, froth and product during the pilot tests.

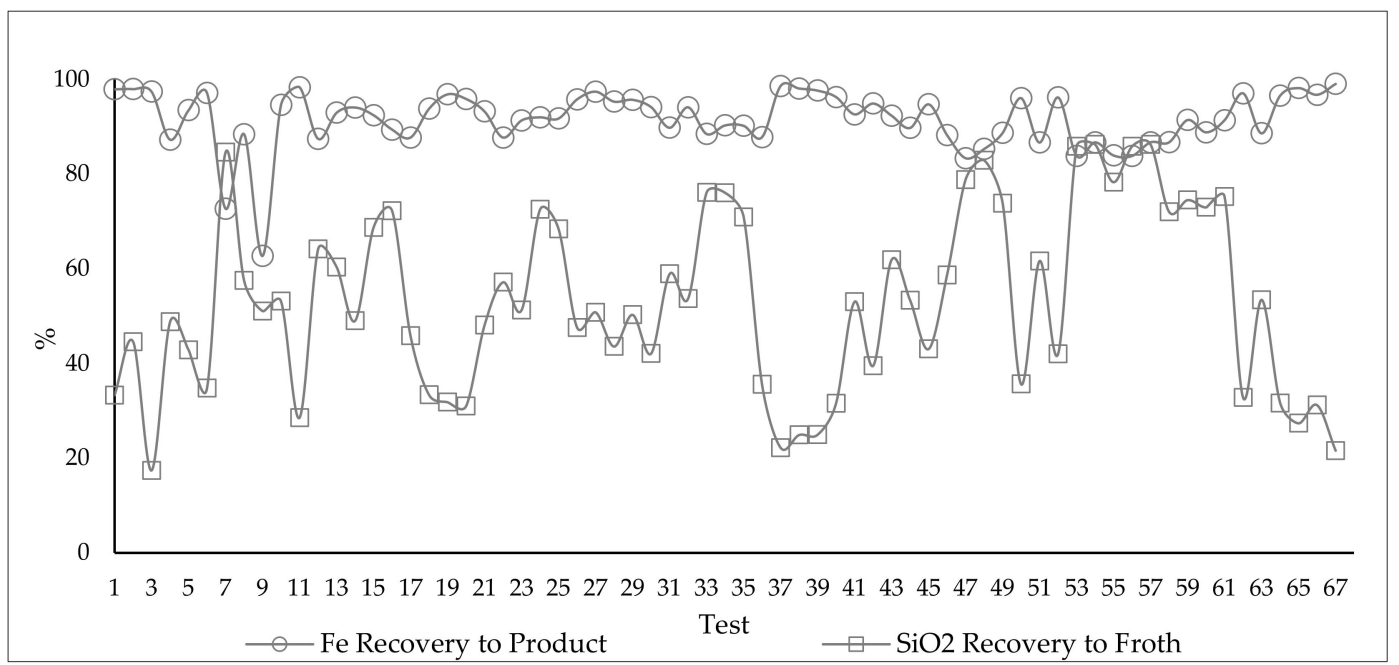

Figure 15. Results concerning the $\mathrm{Fe}$ and $\mathrm{SiO}_{2}$ recoveries during the pilot tests.

Table 6. Summary of results for 67 pilot tests.

\begin{tabular}{|c|c|c|c|c|c|c|c|}
\hline ID & $\%$ Fe Feed & $\%$ Fe Product & $\%$ Fe Tailing & \multicolumn{2}{|c|}{ Mass Recovery } & $\begin{array}{c}\text { Fe Recovery } \\
\text { Product }\end{array}$ & $\mathrm{SiO}_{2}$ Recovery Froth \\
\hline Average Value & 44.5 & 53.3 & 15.2 & \multicolumn{2}{|c|}{76.9} & 91.5 & 53.1 \\
\hline 90th percentile & 47.1 & 59.6 & 21.6 & \multicolumn{2}{|c|}{89.1} & 97.7 & 78.5 \\
\hline Median & 44.6 & 52.6 & 14.1 & \multirow{2}{*}{\multicolumn{2}{|c|}{$\begin{array}{l}76.8 \\
62.8\end{array}$}} & 92.4 & 51.2 \\
\hline 10th percentile & 41.7 & 48.6 & 8.4 & & & 86.1 & 30.0 \\
\hline \multirow{2}{*}{ ID } & \multicolumn{3}{|c|}{$J_{L}\left(\mathrm{~cm} \cdot \mathrm{s}^{-1}\right)$} & \multicolumn{3}{|c|}{$J_{S L}\left(\mathrm{~cm} \cdot \mathrm{s}^{-1}\right)$} & \multirow{2}{*}{$J_{W}\left(\mathrm{~cm} \cdot \mathrm{s}^{-1}\right)$} \\
\hline & Feed & Product & Tail & Feed & Product & Tail & \\
\hline Average Value & 0.18 & 0.25 & 0.07 & 0.20 & 0.26 & 0.08 & 0.14 \\
\hline 90th percentile & 0.20 & 0.29 & 0.13 & 0.22 & 0.31 & 0.14 & 0.19 \\
\hline Median & 0.19 & 0.23 & 0.06 & 0.21 & 0.24 & 0.07 & 0.11 \\
\hline 10th percentile & 0.18 & 0.18 & 0.03 & 0.21 & 0.19 & 0.03 & 0.07 \\
\hline
\end{tabular}


Table 7. Average values per range of variation of the collector, $\%$ Fe in the froth, $J_{L-p}$ product and carrying rate.

\begin{tabular}{|c|c|c|c|c|c|c|c|}
\hline \multicolumn{2}{|c|}{$\begin{array}{c}\text { Range Collector } \\
\left(\mathrm{g} / \mathrm{m}^{3} \text { water_feed }\right) /\left(\% \mathrm{SiO}_{2}\right)\end{array}$} & \multirow{2}{*}{$\begin{array}{c}\% \mathrm{SiO}_{2} \\
\text { Product }\end{array}$} & \multirow{2}{*}{$\begin{array}{c}\begin{array}{c}\text { \%Water } \\
\text { Froth }\end{array} \\
75.7\end{array}$} & \multicolumn{2}{|c|}{ Range Fe Froth \% } & \multirow{2}{*}{$\begin{array}{c}\text { \%Water } \\
\text { Recovery_Froth } \\
12.4\end{array}$} & \multirow{2}{*}{$\frac{J_{W} / J_{S L} \text { Tail }}{2.6}$} \\
\hline from 0 to 0.75 & 0.6 & & & from 0 to 7 & 5.2 & & \\
\hline from 0.75 to 1.85 & 1.5 & 19.2 & 77.8 & from 7 to 14 & 11.3 & 18.3 & 2.4 \\
\hline from 1.85 to 2.95 & 2.2 & 19.0 & 81.7 & from 14 to 21 & 17.2 & 25.0 & 1.7 \\
\hline from 2.95 to 4.05 & 3.3 & 14.0 & 82.6 & from 21 to 28 & 22.4 & 28.8 & 1.4 \\
\hline from 4.05 to 5.15 & 4.2 & 14.1 & 87.5 & from 28 to 35 & 30.6 & 34.9 & 1.2 \\
\hline from 5.15 to 6.25 & 5.7 & 11.2 & 87.0 & from 35 to 42 & 41.0 & 66.3 & 0.9 \\
\hline \multicolumn{2}{|c|}{ Range Water Recovery_Product \% } & \multicolumn{2}{|c|}{ \%Recovery Fe_Product } & \multicolumn{2}{|c|}{ Range Carrying Rate $\left(\mathrm{t} / \mathrm{h} \cdot \mathrm{m}^{2}\right)$} & $\begin{array}{c}\% \text { Fe Recovery } \\
\text { Froth }\end{array}$ & $\begin{array}{c}\% \mathrm{SiO}_{2} \\
\text { Product }\end{array}$ \\
\hline from 0 to 0.8 & 0.7 & \multicolumn{2}{|c|}{87.2} & from 0 to 0.23 & 0.2 & 3.7 & 22.3 \\
\hline from 0.8 to 1.6 & 1.2 & \multicolumn{2}{|c|}{91.4} & from 0.23 to 0.46 & 0.3 & 5.0 & 23.5 \\
\hline from 1.6 to 2.4 & 1.9 & \multicolumn{2}{|c|}{91.5} & from 0.46 to 0.69 & 0.6 & 6.8 & 19.2 \\
\hline from 2.4 to 3.2 & 3.0 & \multicolumn{2}{|c|}{94.1} & from 0.69 to 0.92 & 0.8 & 11.8 & 14.2 \\
\hline from 3.2 to 4 & 3.7 & \multicolumn{2}{|c|}{98.3} & from 0.92 to 1.15 & 1.0 & 19.9 & 11.7 \\
\hline- & - & - & - & from 1.15 to 1.38 & 1.3 & 13.7 & 11.2 \\
\hline
\end{tabular}

\subsubsection{Influence of Collector Dosage}

The trend presented in Figure 16 shows that increasing the dosage of the collector results in a decrease in the silica content in the concentrate.

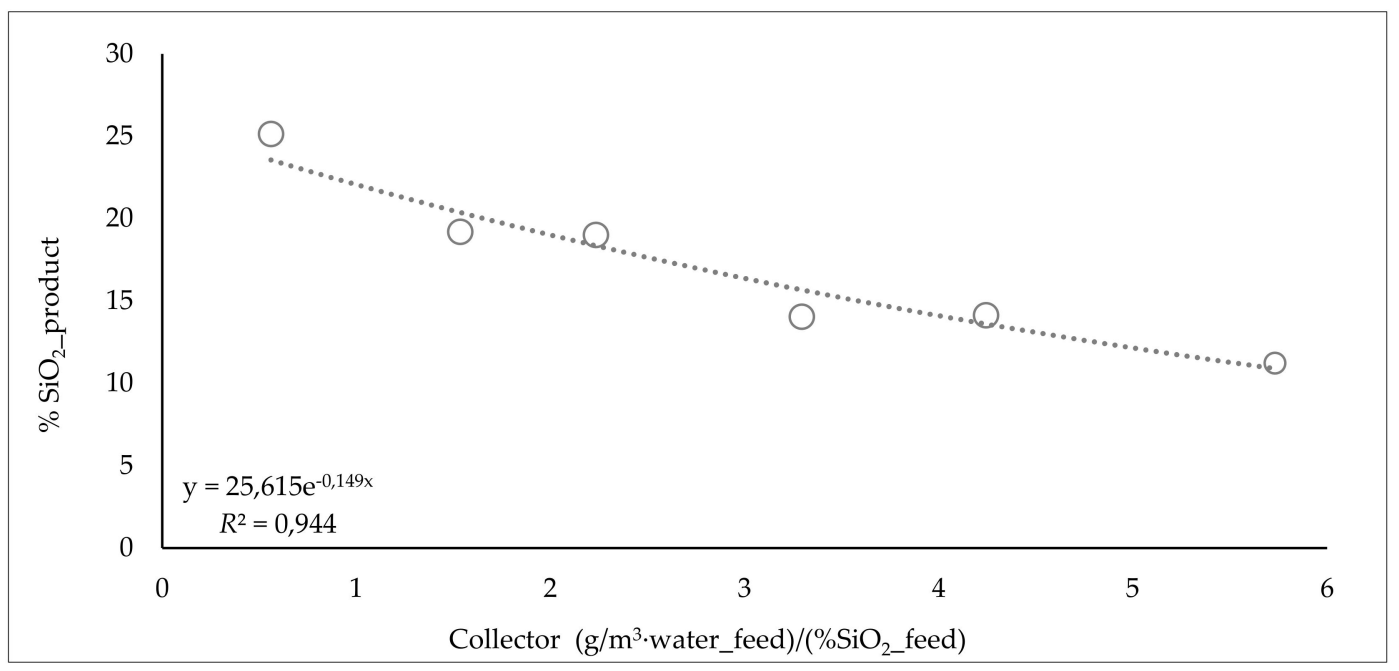

Figure 16. Trend between the amidoamine specific dosage and the $\mathrm{SiO}_{2}$ content in the product concerning.

For a given gas holdup in the collection zone, different water-carrying capacities can be obtained by changing the frother type in the system [40]. The amidoamine is a surfactant, so this reagent performs two functions in the flotation process: collector and frother. Therefore, by increasing the concentration of amidoamine, the bubbles will carry an increasing amount of water (Figure 17).

The amount of water carried with bubbles affects many sub-processes taking place in the froth, which determine the froth product quality [41]. The recovery of fine hydrophilic particles in flotation is related to the recovery of water. Water may be carried by bubbles into the froth [42] and the water recovery is closely related to the nonselective transport of solid particles in the froth by entrainment [43].

\subsubsection{Influence of Water Recovery}

As the amidoamine Flotinor 5530 shows selective behaviour for reverse flotation of quartz in iron ore without depressant, the loss of iron in the froth can be mainly attributed to entrainment. Figure 18 shows the trend of increasing the iron content in the froth due to the increased water recovery. 


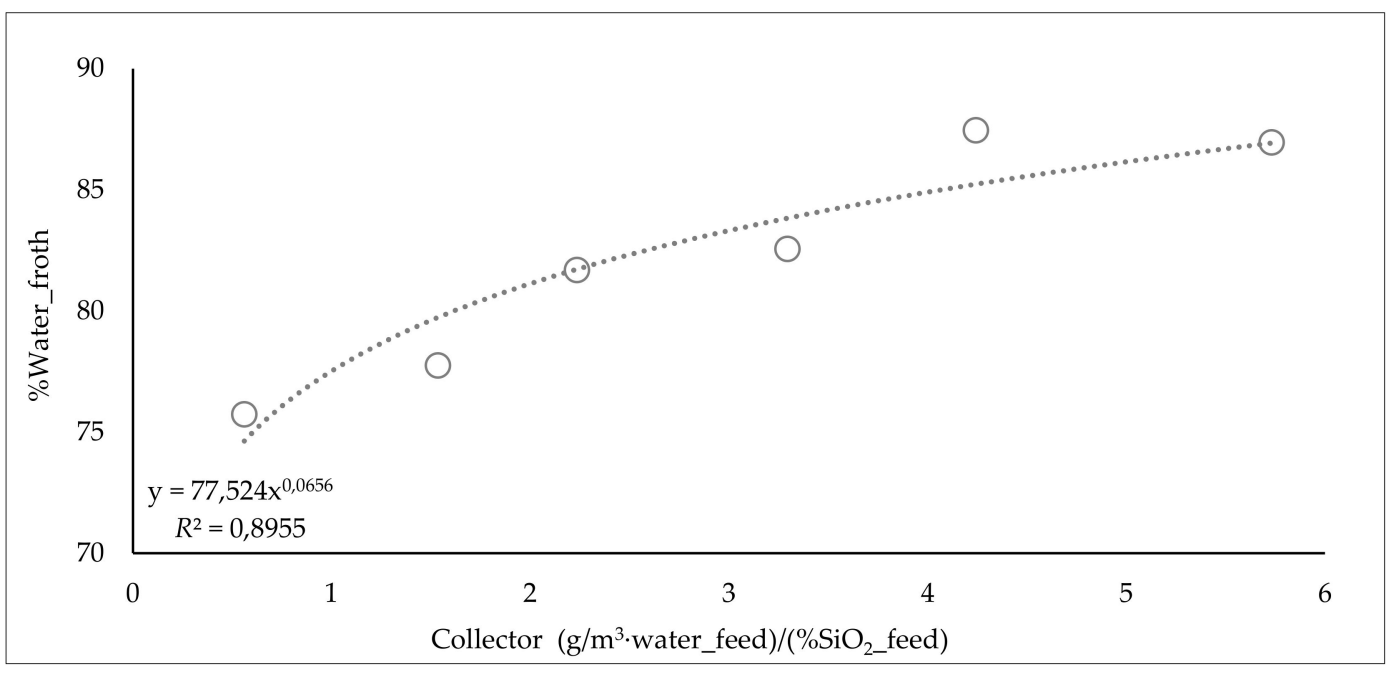

Figure 17. Trend between the amidoamine specific dosage and the \%water in the froth content in the product.

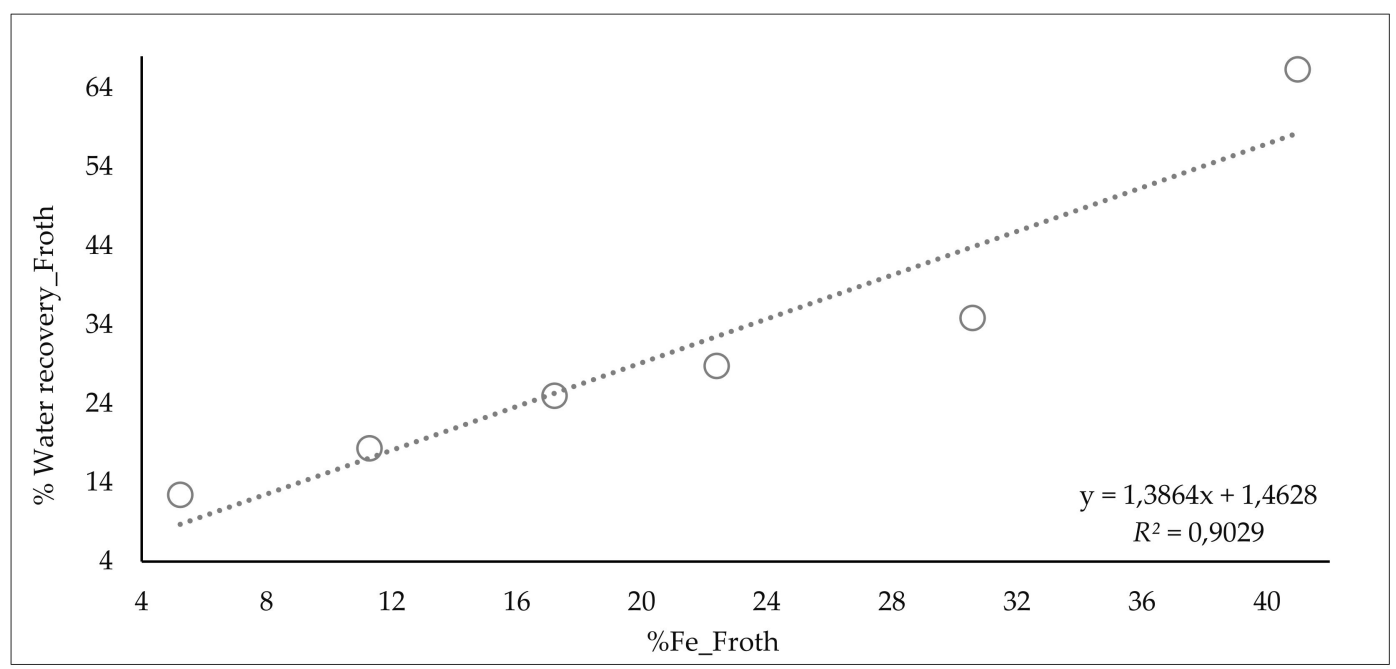

Figure 18. Trend between the Fe content in the froth and the water recovery in the froth.

Figure 19 shows an improvement trend in iron recovery due to the increase in water recovery for the non-floated product.

\subsubsection{Influence of Washing Water}

According to Trahar [10], the entrainment effect can be reduced by decreasing the water flow to the froth, using a suitable choice of frothers and collectors or by reducing pulp densities. However, such methods rarely seem to provide an effective solution in industrial practices. Only column flotation combined with some form of refluxing and froth washing appears to reduce entrainment for the fine particle flotation [44].

Kursun [45] demonstrated that the effect of particle size on the entrainment factor is very significant. The washing water is used in flotation to increase the drainage rate of water within the froth phase, removing entrained (hydrophilic) particles [46]. According to Soto [47], washing water flow helps to stabilize the thick froth layer, reducing the entrainment of fine gangue particles (Figure 20). This makes column flotation a very selective process to separate finely ground minerals. 


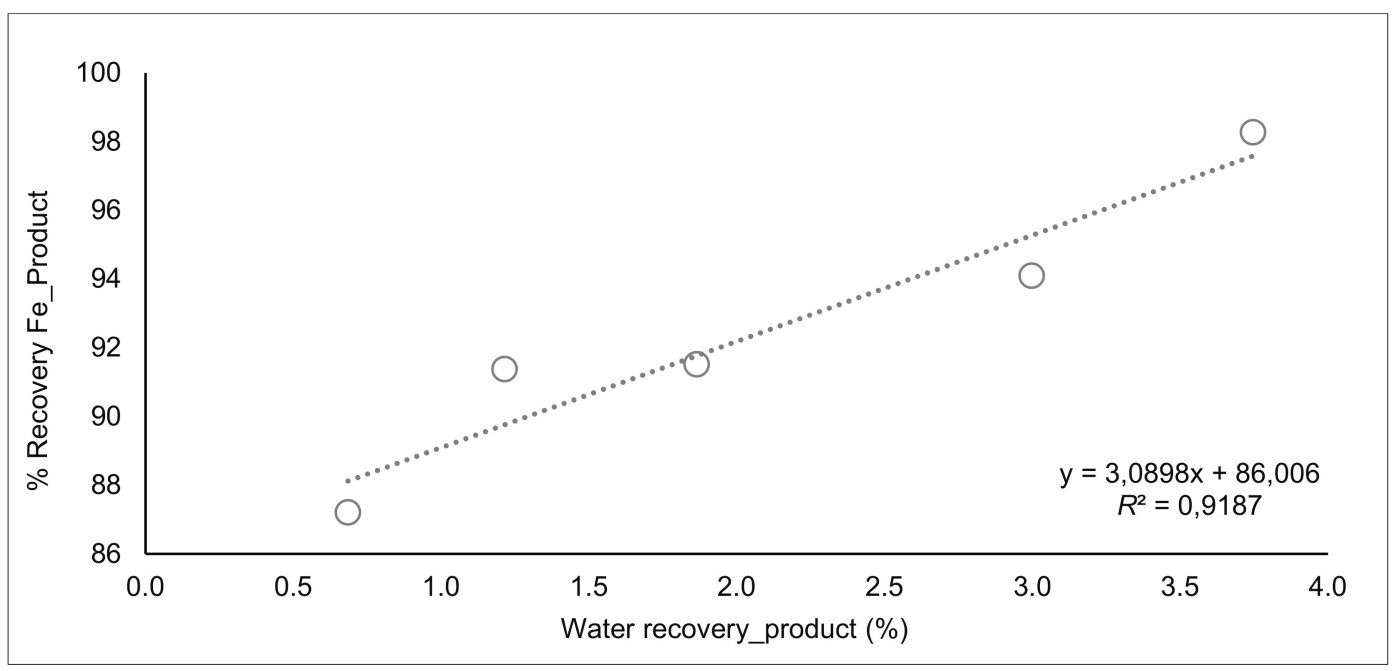

Figure 19. Trend between the water recovery to the product and the recovery of Fe to product.

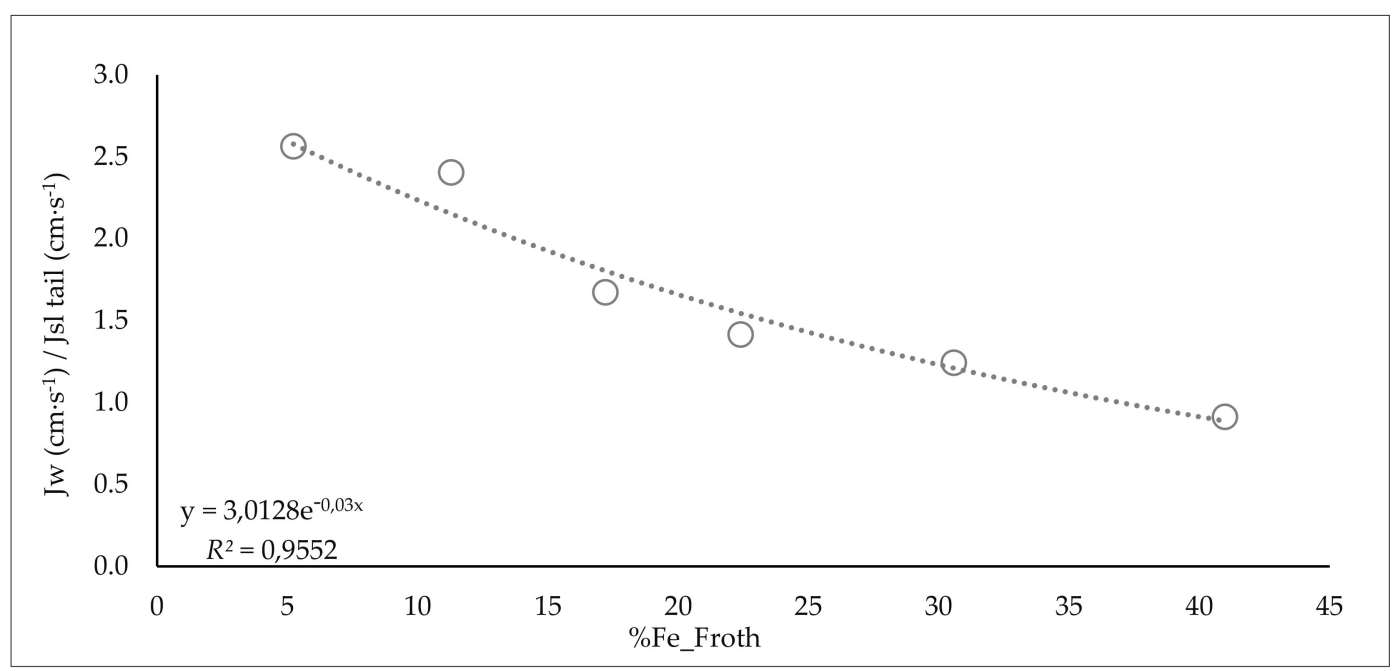

Figure 20. Trend between the Fe content and the $J_{w} / J_{s l}$ tail.

Figure 21 shows the washing water system during the pilot tests.

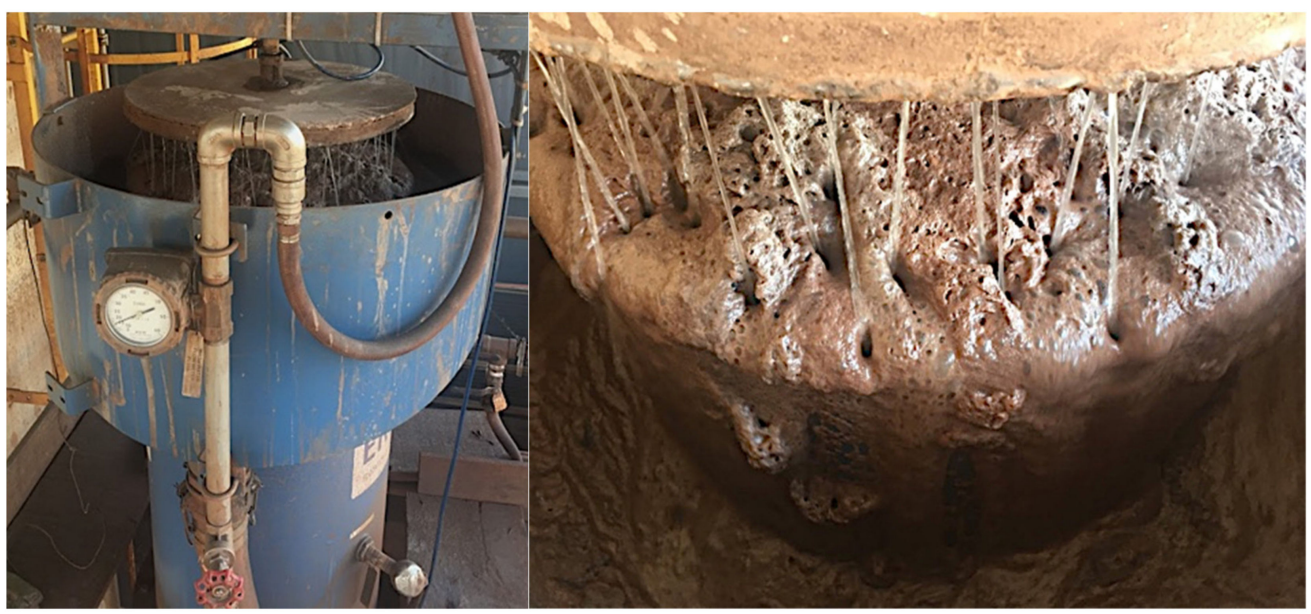

Figure 21. Washing water system during the pilot tests. 


\subsubsection{Carrying Rates}

To find the best column flotation circuit, the design objectives must be clear concerning the grades and recoveries and their allowed variance [48]. Maximum carrying capacity is a critical parameter in enrichment by column flotation [49]. According to Espinosa-Gomez et al. [50], the capacity of a flotation column can be limited by the rate of concentrate removal. Limiting carrying capacity was observed during pilot column flotation of very fine minerals at Mount Isa Mines (MIM), Australia [51].

Espinosa-Gomez et al. [50] showed that the maximum carrying capacity achieved from a flotation column is directly proportional to the product of the d80 particle size and the mean specific gravity of the concentrate. The carrying capacity parameter for iron ore slimes column flotation tends to be lower than the values for conventional iron ore flotation and may vary considerably due to operational adjustments and/or variations in ROM that will imply changes in the granulometry. The trends presented by the carrying capacity values and the $\mathrm{SiO}_{2}$ content in the concentrate and the carrying capacity and recovery of iron in the froth are shown in Figures 22 and 23. These trends indicate that it is difficult to have a low loss of iron in the froth and obtain high iron content $\left(\right.$ low $\left.\mathrm{SiO}_{2}\right)$ in the concentrate by adopting only one concentration stage.

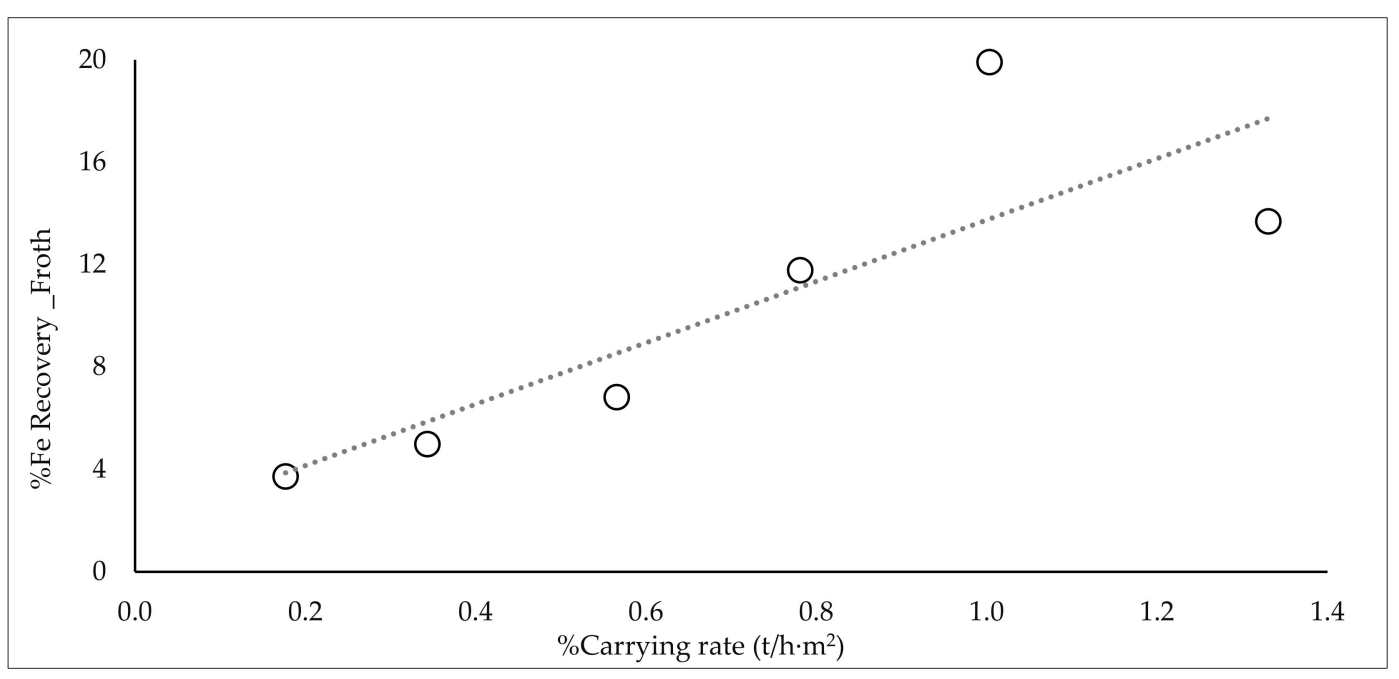

Figure 22. Trend between the carrying rate and Fe recovery to froth concerning the pilot test results.

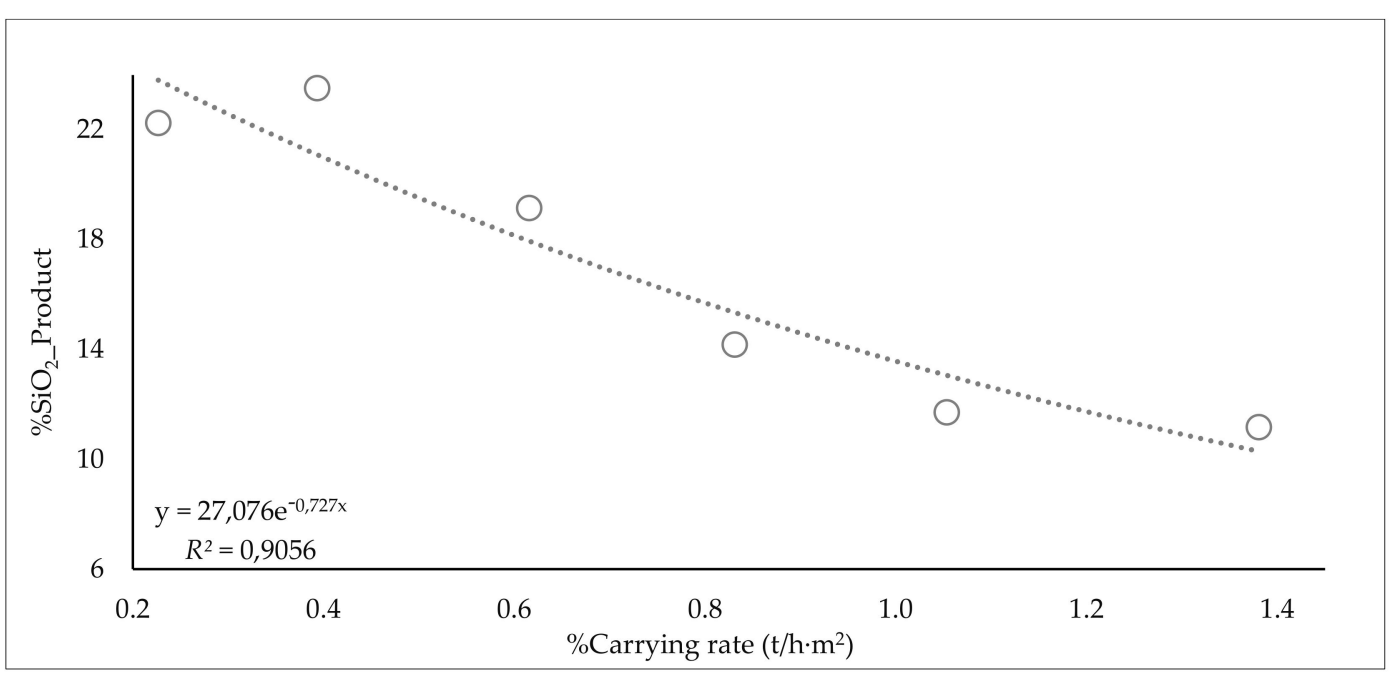

Figure 23. Trend between the carrying rate and $\mathrm{SiO}_{2}$ content in the product concerning the pilot test results. 


\subsection{General Discussions}

\subsubsection{Control System}

According to Bergh and Yianatos [52], stable operation of flotation columns and consequent consistent metallurgical benefits can only be obtained if basic distributed control systems are implemented. Considering the high variation of the slime characteristics from the industrial plant $\left(\% \mathrm{Fe}, \% \mathrm{SiO}_{2}, \% \mathrm{Al}_{2} \mathrm{O}_{3}, \%\right.$ solids), the adoption of an industrial slimes flotation process as rougher stage needs to be supported by reagent dosing and wash water automatic control systems with online instrumentation to analyze the $\mathrm{Fe}$ and $\mathrm{SiO}_{2}$ content.

The optimum superficial air velocity for each pilot test was not evaluated in this work. Mackay et al. [4] highlighted the importance of considering the connection between particle size, air rate and froth stability when determining flotation strategies. Thus, the implementation of automatic air flow control in the cavitation system can also contribute to improve the results obtained in a slime flotation industrial circuit since, in addition to the variability of the run of mine, some adjustments in the industrial plant may change the size distribution of the slimes flotation feed, requiring a new optimized air flow, since these changes in the particle size distribution require a change in the air rate to maximize mineral recovery [5].

\subsubsection{Product Quality and the Challenge of Slimes Concentration in Brazil}

Several factors may have influenced the results of the flotation process, such as mineralogical characteristics that may be related to gangue minerals or even to iron oxides. Figure 24 shows the tendency to reduce the iron content in the flotation product due to the increase in LOI (loss of ignition) in this same product.

The presence of goethite, gibbsite, and kaolinite leads to high LOI (loss on ignition) and high Blaine number (a technical parameter which quantifies the proportion of the clayey minerals, i.e., kaolinite) in the iron ore concentrate after beneficiation [53]. The iron oxides in the itabirite slimes of the Iron Quadrangle consist mainly of hematite and goethite. The more goethite is present in the slimes, in addition to the reduction of the Fe content due to the chemical composition of the goethite, the LOI associated with this iron oxide decreases the maximum possible iron content to be obtained in the concentrate. Considering the same mineralogical constitution, the higher the Blaine, the larger amount of reagent is needed to obtain the concentrates due to the increase in the mineral surfaces to absorb the collector. In relation to the flotation process, the increase in the dosage of the collector, in addition to the presence of more ultrafine particles and its mineralogical constitution, render it difficult to obtain products of high chemical quality without considerable reduction in mass recovery.

Regarding another processes, such as the magnetic concentration, the relative importance of the particle size is a critical point in the process of magnetic concentration because, while the hydrodynamic drag force is proportional to the particle diameter, the magnetic and gravitational forces are proportional to the particle volume [54]. Thus, for ultrafine particle size, the magnetic concentration tends to generate high levels of iron in the tailings due to the increase in the hydrodynamic drag of these particles.

Studies have been carried out on the concentration and reuse of iron slimes in Brazil, considering not only unique processes, but also the combination of processes such as magnetic concentration and flotation. The main objective of the Brazilian iron ore mining companies is to reduce the amount of slimes generated at their plants. The definition of the ore is based on economic criteria, therefore, the feasibility of a slime concentration process must be analyzed not only by the quality of the product generated, but, above all, by the avoided costs. Even generating lower quality products, the concentration of the slime decreases the volume of material sent to tailings dams, reducing environmental and safety risks. 


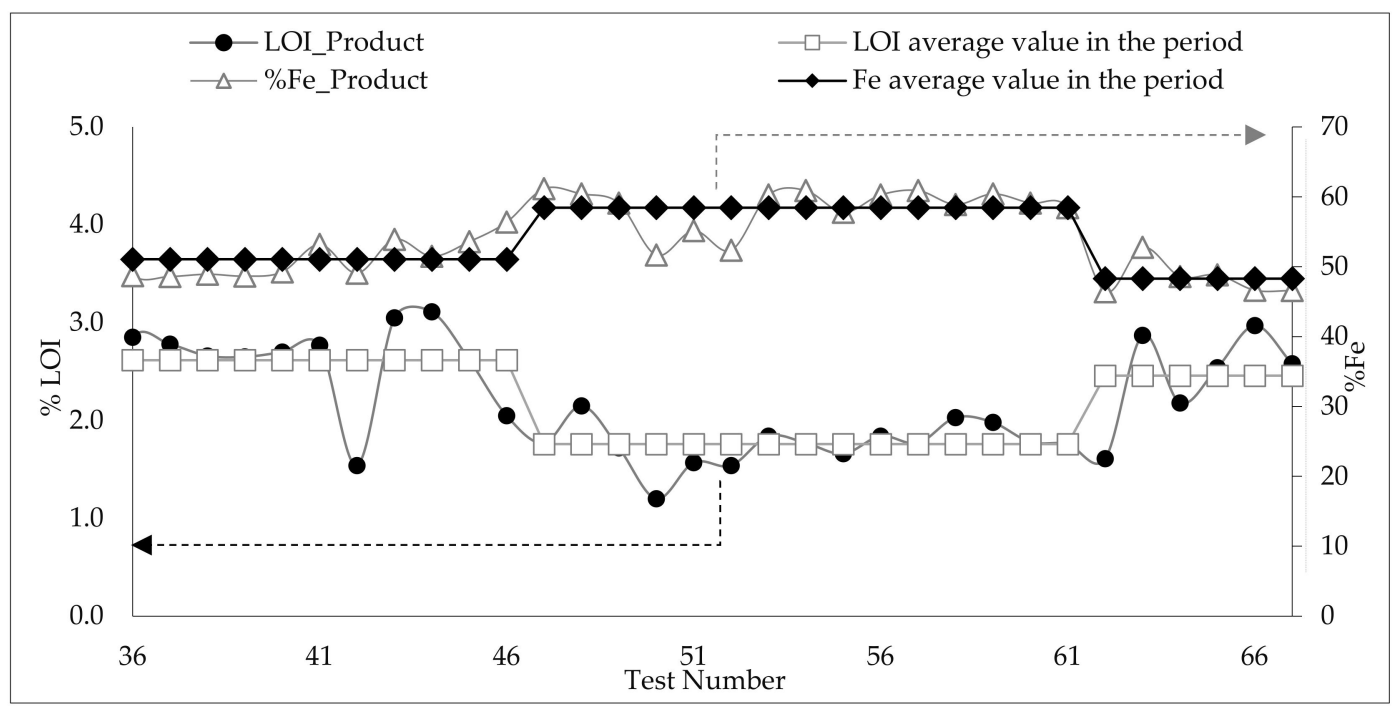

Figure 24. Trend regarding the reduction of the iron content in the product with the increase in the value of LOI for this concentrate.

\section{Conclusions}

The Flotinor 5530 amidoamine showed selective behaviour as collector in reverse column flotation of quartz with no depressant from Vargem Grande 2 iron ore slimes. A concentrate with iron grade of up to $61 \% \mathrm{Fe}$ and metallurgical recovery of $85.7 \%$ were achieved in one rougher stage only from the slimes containing $46.5 \%$ Fe. The fluctuation of the flotation performance of the continuous column flotation were related to the variability of the slimes characteristics in the industrial plant.

The loss of iron in the tailings was correlated with entrainment effect, thus the adjustment of the specific collector dosage and the relationship between the washing water and the froth volume are important factors to control the flotation performance. The implementation of automatic control systems regarding these parameters will improve the performance of an eventual slimes flotation industrial application.

The increased values of the carrying rate decreases the $\mathrm{SiO}_{2}$ content in the iron concentrate to the detriment of the increased losses of iron in the froth product (tailings). Thus, there is no guarantee to reach high iron metallurgical recovery and low $\mathrm{SiO}_{2}$ content in the concentrate, adopting only one column flotation stage during an industrial operation.

The iron content in the product varies according to the mineralogical characteristics of the slimes and, for high LOI values in the concentrate, there is a tendency to obtain low iron content in the nonfloated product.

Further studies regarding the adoption of a cleaner stage by flotation or magnetic concentration will contribute to the feasibility of implementing an iron ore slimes concentration circuit in the Vargem Grande 2 plant concentrator.

Author Contributions: Conceptualization, L.O.F., K.S. and N.L.; data curation, K.S., A.P., N.L., I.S. and I.V.F.; formal analysis, K.S., A.P., L.B. and I.V.F.; funding acquisition, K.S. and N.L.; investigation, K.S., N.L. and A.E.C.P.; methodology, L.O.F., K.S., A.P., N.L. and A.E.C.P.; project administration, K.S. and N.L.; resources, I.S. and L.B.; supervision, L.O.F. and N.L.; validation, L.O.F., K.S., N.L., L.B., I.V.F. and A.E.C.P.; visualization, I.S., L.B. and I.V.F.; writing-original draft, K.S. and A.P.; writing-review \& editing, L.O.F., I.S. and A.E.C.P. All authors have read and agreed to the published version of the manuscript.

Funding: This research received no external funding.

Data Availability Statement: Not applicable. 
Acknowledgments: This paper was supported by VALE S.A in the context of developing beneficiation routes for iron ore slimes. The support of Clariant, Brazil is deeply appreciated. The support of Vale Institute of Technology is also acknowledged. L.F. and I.F. acknowledge the support provided by H2020 Fine Future project under grant agreement No. 821265.

Conflicts of Interest: The authors declare that they have no conflicts of interest or competing financial interests.

\section{References}

1. Clemmer, J.B. Flotation of iron ore. In Proceedings of the 8th Annual Mining Symposium, Duluth, MN, USA, 15 January 1947.

2. Filippov, L.; Severov, V.; Filippova, I. An overview of the beneficiation of iron ores via reverse cationic flotation. Int. Nat. J. Miner. Process. 2014, 127, 62-69. [CrossRef]

3. Achaye, I. Effect of Mineral Particle Size on Froth Stability. Ph.D. Thesis, University of Cape Town, Cape Town, South Africa, March 2017.

4. Mackay, I.; Videla, A.R.; Brito-Parada, P.R. The link between particle size and froth stability - Implications for reprocessing of flotation tailings. J. Clean. Prod. 2020, 242, 118436. [CrossRef]

5. Norori-McCormac, A.; Brito-Parada, P.R.; Hadler, K.; Cole, K.; Cilliers, J.J. The effect of particle size distribution on froth stability in flotation. Sep. Purif. Technol. 2017. [CrossRef]

6. Rocha, L.; Cançado, R.Z.L.; Peres, A.E.C. Iron ore slimes flotation. Miner. Eng. 2010, 23, 842-845. [CrossRef]

7. Haselhuhn, H.J.; Kawatra, K. Effects of Water Chemistry on Hematite Selective Flocculation and Dispersion. Miner. Process. Extr. Metall. Rev. 2015, 36, 305-309. [CrossRef]

8. Houot, R. Beneficiation of iron ore by flotation-Review of industrial and potential applications. Int. J. Miner. Process. 1983, 10, 183-204. [CrossRef]

9. Weissenborn, P.K.; Warren, L.J.; Dunn, J.G. Optimisation of selective flocculation of ultrafine iron ore. Int. J. Miner. Process. 1994, 42, 191-213. [CrossRef]

10. Trahar, W.J. A rational interpretation of the role of particle size in flotation. Int. J. Miner. Process. 1981, 8, 289-327. [CrossRef]

11. Sivamohan, R. The Problem of Recovering Very Fine Particles in Mineral Processing-A Review. Int. J. Miner. Process. 1990, 28, 247-288. [CrossRef]

12. Gontijo, C.F.; Fornasiero, D.; Ralston, J. The Limits of Fine and Coarse Particle Flotation. Can. J. Chem. Eng. 2007, 85, 562-785.

13. Farrokhpay, S.; Filippova, I.; Filippov, L.; Picarra, A.; Rulyov, N. Flotation of fine particles in the presence of combined microbubbles and conventional bubbles. Miner. Eng. 2020, 155. [CrossRef]

14. Oliveira, H.; Azevedo, A.; Rubio, J. Nanobubbles generation in a high-rate hydrodynamic cavitation tube. Miner. Eng. 2017. [CrossRef]

15. Fan, M.; Zhao, Y.; Tao, D. Fundamental studies of nanobubble generation and applications in flotation. In Separation Technologies for Minerals Coal and Earth Ressources; SME: Littleton, CO, USA, 2012; pp. 457-469.

16. Lima, N.P.; Pinto, T.C.S.; Tavares, A.C.; Sweet, J. The entrainment effect on the performance of iron ore reverse flotation. Miner. Eng. 2016. [CrossRef]

17. Lima, R.M.F.; Abreu, F.P.V.F. Characterization and concentration by selective flocculation/magnetic separation of iron ore slimes from a dam of Quadrilátero Ferrífero-Brazil. J. Mater. Res. Technol. 2020, 9, 2021-2027. [CrossRef]

18. Ma, X.; Bruckard, W.J.; Holmes, R. Effect of collector, $\mathrm{pH}$ and ionic strength on the cationic flotation of kaolinite. Int. J. Miner. Process. 2009, 93, 54-58. [CrossRef]

19. Xu, L.; Hu, Y.; Faqin, D.; Hao, J.; Wu, H.; Zhen, W.; Ruohua, L. Effects of particle size and chain length on flotation of quaternary ammonium salts onto kaolinite. Min. Pet. 2014. [CrossRef]

20. Ma, X.; Bruckard, W.J. The effect of $\mathrm{pH}$ and ionic strength on starch-kaolinite interactions. Int. J. Miner. Process. 2010, 94, 111-114. [CrossRef]

21. Nykänen, V.P.S.; Braga, A.S.; Pinto, T.C.S.; Matai, P.H.L.S.; Lima, N.P.; Filho, L.S.L.; Monte, M.B.M. True flotation versus entrainment in reverse cationic flotation for the concentration of iron ore at industrial scale. Miner. Process. Extr. Metall. Rev. 2018, 41. [CrossRef]

22. Filippov, L.; Filippova, I.; Severov, V. The use of collectors mixture of various molecular structure in the reverse cationic flotation of magnetite ore. Miner. Eng. 2020, 23, 91-98. [CrossRef]

23. Filippov, L.; Severov, V.; Filippova, I. Mechanism of starch adsorption on Fe-Mg-Al-bearing amphiboles. Int. J. Miner. Process. 2013, 123, 120-128. [CrossRef]

24. Severov, V.; Filippova, I.; Filippov, L. Floatability of Fe-bearing silicates in the presence of starch: Adsorption and spectroscopic studies. J. Phys. Conf. Ser. 2013, 416, 012017. [CrossRef]

25. Veloso, C.H.; Filippov, L.O.; Filippova, I.; Ouvrard, S.; Araujo, A.C. Adsorption of polymers onto iron oxides: Equilibrium isotherms. J. Mater. Res. Technol. 2019, 9, 779-788. [CrossRef]

26. Araujo, V.A.; Lima, N.P.; Azevedo, A.; Rubio, J. Column reverse rougher flotation of iron bearing fine tailings assisted by HIC and a new cationic collector. Miner. Eng. 2020, 156. [CrossRef]

27. Matiolo, E.; Couto, H.J.B.; Lima, N.; Klaydison, S. Improving recovery of iron using column flotation of iron ore slimes. Miner. Eng. 2020, 158. [CrossRef] 
28. Klaydison, S.; Filippov, L.; Piçarra, A.; Filippova, I.; Lima, N.; Skliar, A.; Filho, L. New perspectives in iron ore flotation: Use of collector reagents without depressants in reverse cationic flotation of quartz. Miner. Eng. 2021, 170. [CrossRef]

29. Ma, X.; Marques, M.; Gontijo, C. Comparative studies of reverse cationic/anionic flotation of Vale iron ore. Int. J. Miner. Process. 2011, 100, 179-183. [CrossRef]

30. Fornasiero, D.; Filippov, L. Innovations in the flotation of fine and coarse particles. J. Phys. Conf. Ser. 2017, 879. [CrossRef]

31. Clout, J.M.F.; Manuel, J.R. Minealogica, chemical and physical characteristics of iron ore. In Iron Ore Mineralogy, Processing and Environmental Sustaibability; Elsevier: Amsterdam, The Netherlands, 2015.

32. Bruckard, W.J.; Smith, L.K.; Heyes, G.W. Developments in the physiochemical separation of iron ore. In Iron Ore; Woodhead Publishing: Sawston, UK, 2015; pp. 339-356. [CrossRef]

33. Trahar, W.J.; Warren, L.J. The flotability of very fine particles-A review. Int. J. Miner. Process. 1976, 3, 103-131. [CrossRef]

34. Araujo, A.C.; Amarante, S.C.; Souza, C.C.; Silva, R.R.R. Ore mineralogy and its relevance for selection of concentration methods in processing of Brazilian iron ores. Miner. Process. Extr. Metall. 2003, 112, 54-64. [CrossRef]

35. Lima, N.P.; Valadão, G.E.S.; Peres, A.E.C. Effect of particles size range on iron ore flotation. Rem: Rev. Esc. De Minas 2013, 66. [CrossRef]

36. Schulze, H.J.; Radoev, B.; Geidel Th Stechemesser, H.; Topfer, E. Investigations of the Collision Process between Particles and Gas Bubbles in Flotation-A Theoretical Analysis. Int. J. Miner. Process. 1989, 27, 263-278. [CrossRef]

37. Chipfunhu, D.; Zanin, M.; Grano, S. Flotation behaviour of fine particles with respect to contact angle. Chem. Eng. Res. Des. 2012, 90, 26-32. [CrossRef]

38. Scheludko, A.; Toshev, B.V.; Bojadjiev, D.T. Attachment of Particles to a Liquid Surface (Capillary Theory of Flotation). J. Chem. Soc. Faraday Trans. 1: Phys. Chem. Condens. Phases 1976, 72. [CrossRef]

39. Souza, H.S.; Braga, A.S.; Oliveira, A.H.; Filho, L.S.L. Concentration of manganese tailings via reverse flotation in an acid médium. Rem: Rev. Esc. De Minas 2016, 69, 85-90. [CrossRef]

40. Kracht, W.; Orozco, Y.; Acuña, C. Effect of surfactant type on the entrainment factor and selectivity of flotation at laboratory scale. Miner. Eng. 2016, 92, 216-220. [CrossRef]

41. Melo, F.; Laskowski, J.S. Effect of frothers and solid particles on the rate of water transfer to froth. Int. J. Miner. Process. 2007, 84, 33-40. [CrossRef]

42. Moyo, P.; Gomes, C.O.; Finch, J.A. Characterizing frothers using water carrying rate. Can. Metall. Q. 2007, 46, 215-220. [CrossRef]

43. Matos, V.E.; Nogueira, S.C.S.; Silva, G.; Kowalczuk, P.B. Differences in Etheramines Froth Properties and the Effects on Iron Ore Flotation. Part II: Three-Phase Systems. Miner. Process. Extr. Metall. Rev. 2021. [CrossRef]

44. Somasundaran, P. Fine particles treatment. In Workshop on Research Needs in Mineral Processing; Columbia University: New York, NY, USA, 1976.

45. Kursun, H. Effect of Fine Particles' Entrainment on Conventional and Column Flotation. Part. Sci. Technol. 2014, 32, 251-256. [CrossRef]

46. Tan, J.; Wang, J.; Nguyen, A.V.; Xie, G. Regimes of drainage instability caused by wash water. Miner. Eng. 2020, 148, 160202. [CrossRef]

47. Soto, H.S. Column flotation with negative bias. In Proceedings of the International Symposium on Processing of Complex Ores, Halifax, UK, 20-24 August 1989; pp. 379-385.

48. Flint, I.M.; Wyslouzil, H.E.; Andrade, V.L.L.; Murdock, D.J. Column flotation of iron ore. Miner. Eng. 1992, 10-12, 1185-1194. [CrossRef]

49. Kursun, H. Determination of Carrying Capacity Using Talc in Column Flotation. Arab. J. Sci. Eng. 2011, 36, 703. [CrossRef]

50. Espinosa-Gomez, R.; Finch, J.A.; Yianatos, J.B.; Dobby, G.S. Technical Note: Flotation Column Carrying Capacity: Particle SIZE and Density Effects. Miner. Eng. 1988, 1 N1,77-79. [CrossRef]

51. Yianatos, J.B.; Contreras, F.A. On the Carrying Capacity Limitation in Large Flotation Cells. Can. Metall. Q. 2010, 49, 345-352. [CrossRef]

52. Bergh, L.G.; Yianatos, J.B. Flotation column automation: State of the art. Control Eng. Pract. 2003, 11, 67-72. [CrossRef]

53. Beuria, P.C.; Biswal, S.K.; Mishra, B.K.; Roy, G.G. Study on kinetics of thermal decomposition of low LOI goethetic hematite iron ore. Int. J. Min. Sci. Technol. 2017. [CrossRef]

54. Svoboda, J.; Fujita, T. Recent developments in magnetic methods of material separation. Miner. Eng. 2003, 16, 785-792. [CrossRef] 